\title{
Ambient noise tomography of the southern sector of the Cantabrian Mountains, NW Spain
}

\author{
Jorge Acevedo ${ }^{\circledR},{ }^{1}$ Gabriela Fernández-Viejo, ${ }^{1}$ Sergio Llana-Fúnez, ${ }^{1}$ \\ Carlos López-Fernández ${ }^{1}$ and Javier Olona ${ }^{1,2}$ \\ ${ }^{1}$ Department of Geology, University of Oviedo, C/ Arias de Velasco s/n, 33005 Oviedo, Spain.E-mail: jacevedo@geol.uniovi.es \\ ${ }^{2}$ TerraDat Ltd., Unit 1, Link Trade Park, Penarth Road, Cardiff CF11 8TQ, United Kingdom.
}

Accepted 2019 July 1. Received 2019 May 30; in original form 2019 February 8

\begin{abstract}
SUMMAR Y
This study presents the first detailed analysis of ambient noise tomography in an area of the continental upper crust in the Cantabrian Mountains (NW Spain), where a confluence of crustal scale faults occurs at depth. Ambient noise data from two different seismic networks have been analysed. In one side, a 10-short-period station network was set recording continuously for 19 months. A second set of data from 13 broad-band stations was used to extend at depth the models. The phase cross-correlation processing technique was used to compute in total more than 34000 cross-correlations from 123 station pairs. The empirical Green's functions were obtained by applying the time-frequency, phase-weighted stacking methodology and provided the emergence of Rayleigh waves. After measuring group velocities, Rayleigh-wave group velocity tomographic maps were computed at different periods and then they were inverted in order to calculate $S$-wave velocities as a function of depth, reaching the first $12 \mathrm{~km}$ of the crust.

The results show that shallow velocity patterns are dominated by geological features that can be observed at the surface, particularly bedding and/or lithology and fracturing associated with faults. In contrast, velocity patterns below $4 \mathrm{~km}$ depth seem to be segmented by large structures, which show a velocity reduction along fault zones. The best example is the visualization in the tomography of the frontal thrust of the Cantabrian Mountains at depth, which places higher velocity Palaeozoic rocks over Cenozoic sediments of the foreland Duero basin. One of the major findings in the tomographic images is the reduction of seismic velocities above the area in the crust where one seismicity cluster is nucleated within the otherwise quiet seismic area of the range. The noise tomography reveals itself as a valuable technique to identify shear zones associated with crustal scale fractures and hence, lower strain areas favourable to seismicity.
\end{abstract}

Key words: Crustal imaging; Seismic interferometry; Seismic noise; Seismic tomography; Fractures, faults, and high strain deformation zones; Intra-plate processes.

\section{INTRODUCTION}

Seismic noise is no longer regarded as an unwanted signal that masks the waves produced by earthquakes or explosions. This is possible thanks to the development of the seismic interferometry theory (e.g. Campillo \& Paul 2003; Wapenaar 2003, 2004; Shapiro \& Campillo 2004; Snieder 2004; Shapiro et al. 2005; Slob et al. 2007; Wapenaar et al. 2011), which allows us to transform ambient seismic noise into a useful seismic signal that registers the distribution of seismic velocities within the propagating medium and leads us to create images by tomographic methods. The main advantage of this approach is that, due to the ubiquitous presence of noise sources, it can be applied in areas of low seismic activity. Furthermore, the empirical Green's function (EGF) of the propagation medium between two receptors can be reconstructed by cross-correlating the seismic noise simultaneously recorded by them (Weaver \& Lobkis 2001; Wapenaar 2003, 2004). The obtained EGF can be interpreted as the seismogram that will be recorded in one of the receptors if the other is acting as an impulsive seismic source (Wapenaar 2004).

Ambient seismic noise is typically dominated by oceanic microseisms (Berger et al. 2004; McNamara \& Buland 2004; Hillers et al. 2012), showing two peaks around frequencies of $0.05-0.10$ and $0.1-0.2 \mathrm{~Hz}$. Microseismic noise propagates predominantly as surface waves (Rayleigh and Love) and therefore the calculated EGFs are dominated by the surface wave component. Given the dispersive character of surface waves, different periods allow us to sample the properties of the propagation medium at different depths by constructing the dispersion curves from the cross-correlations. 
Then we can perform tomographic inversions using the surface wave velocities for each period as input (e.g. Shapiro et al. 2005; Sabra et al. 2005; Villaseñor et al. 2007; Yang et al. 2007; Lin et al. 2008; Mottaghi et al. 2013; Silveira et al. 2013; Nicholson et al. 2014; Dias et al. 2015). Finally, the inversion of group velocities in each point of a grid can be used to obtain layered profiles of $S$-wave velocity, which are further interpolated to compute 2-D maps. The application of this technique to improve the knowledge of the crust and the upper mantle in continental scale studies is widely acknowledged. In fact, in recent years, the number of small or local-scale studies has grown significantly due to its great applicability in fields like hydrocarbon exploration (Bussat \& Kugler 2009), geological engineering (Picozzi et al. 2009), fluid injection monitoring (Stork et al. 2018), volcanology (e.g. Ryberg et al. 2016; Wang et al. 2017) or fault mapping (Li \& Lin 2014; Zigone et al. 2015; Brandmayr et al. 2016). To date, in the Iberian Peninsula, few regional ambient noise tomography studies have been done inland (Villaseñor et al. 2007; Silveira et al. 2013; Palomeras et al. 2017) or in the continental margins (Corela et al. 2017). At a larger scale, Macquet et al. (2014) have obtained tomographic maps of the north of Spain as part of a broader study of the Pyrenees.

In this work, we aimed to use the ambient noise recordings of two different-scale seismic networks to elucidate the structure at depth of the upper crust in NW Iberia, especially around the seismically active area inland that coincides with the southern segment of the Ventaniella fault, within an otherwise quiet area (Fig. 1). This fault crosses the Cantabrian Mountains, an Alpine chain formed as a prolongation to the west of the Pyrenees (Fig. 1), involving the convergence of continental and oceanic crust from the Bay of Biscay. The mountain belt developed a local crustal root in the eastern side (Boillot et al. 1979; Pulgar et al. 1996; Álvarez-Marrón et al. 1997; Fernandez-Viejo et al. 1998). The trace of the Ventaniella fault at the surface coincides partly with the western boundary of the Alpine orogenic root. The seismicity, recently studied by LopezFernández et al. (2018), clusters within the southeastern part of the range, along a sector traversing the current watershed of the mountain belt. Although residual isostatic stresses cannot be discarded to have played a role in feeding the seismicity, considering its location associated with a significant gradient in crustal thickness, it has been interpreted as related to the intersection of crustal-scale faults in the Cantabrian Mountains (Fig. 1), in particular the NW-SE Ventaniella fault, the E-W frontal thrust of the Cantabrian Mountains and other NW-SE and E-W faults (Tarna, León; López-Fernández et al. 2018).

Altogether, we have analysed a continuous seismic data set (non-simultaneous) from a total of 23 stations. First, we computed 12 months (year 2012) of broad-band data from 12 stations deployed in the framework of the IberArray project (Díaz et al. 2009; Fig. 2), together with an additional Spanish permanent network station (Fig. 2). Moreover, we have included in the study 19 month of continuous data from the data set provided by 10 short-period stations, recorded between September 2015 and March 2017 (Fig. 2). For the 123 station pairs, we have obtained a total of 34526 daily cross-correlations by using the phase crosscorrelation (PCC) processing technique (Schimmel 1999). Next, all the available daily cross-correlations between each station pair were stacked with the time-frequency, phase-weighted methodology (tf-PWS; Schimmel \& Gallart 2007) in order to obtain the EGFs.

The ambient noise tomography maps have given us some insights into the physical characteristics of the fault blocks and their crustal structure in the Cantabrian Mountains, which are reliable within the first $12 \mathrm{~km}$. The small short-period array provided valuable additional paths at shorter periods, which led to an improved resolution in the area where the local seismicity clusters appear. The study illustrates the feasibility of using ambient noise tomography in lowmagnitude seismic zones to conduct tectonic studies focused on subsurface structures of interest for geodynamical and/or seismological reasons.

\section{TECTONIC SETTING}

The boundary between Europe and Africa during the Alpine convergence was located to the north of the Iberian Peninsula, (Roest \& Srivastava 1991) resulting in the formation of the Pyrenees (Fig. 1), where the convergence involved continental crust on either side (Muñoz 1992, 2002), and the Cantabrian Mountains, to the west (Fig. 1), where there was involvement of continental crust to the south and oceanic crust to the north (e.g. Boillot et al. 1979; Álvarez-Marrón 1997; Fernández-Viejo et al. 1998). The formation of the Cantabrian Mountains involved the development of a crustal root in its eastern half that loses entity towards the west (e.g. Choukroune \& ECORS Team 1989; Pulgar et al. 1996; FernándezViejo et al. 2000; Ruiz 2007). At the surface, the transition between both domains within the crust coincides roughly with the trace of the Ventaniella fault (Fig. 1).

The amount of cumulative Alpine shortening decreases from a maximum at the Pyrenees (90-165 km, Muñoz 1992; Mouthereau et al. 2014; Teixell et al. 2018) to being nominally zero at the western end of the Iberian Peninsula (Martín-González \& Heredia 2011; Llana-Fúnez \& López-Fernández 2015). In the central part of the Cantabrian Mountains, where this study is based, the amount of shortening onshore was estimated to be between 20 and $24 \mathrm{~km}$ from geological cross-sections (Alonso et al. 1996).

Prior to the Alpine orogeny, two major rifting episodes occurred in northern Iberia, varying in intensity and kinematics. The first episode, during late Permian-early Triassic, generated faults with a northwesterly trend. Offshore, normal faults with Permian-Triassic deposits in the hanging wall have relatively high angle (LopezGomez et al. 2019). Between late Jurassic and early Cretaceous, a major extensional episode produced the opening of the Bay of Biscay and the current crustal structure mostly to the east of the study area, for example, the Basque-Cantabrian basin. Details on the effects on the continental margin and the nature of the extension can be found in Cadenas et al. (2018).

In Palaeocene times, the convergence between Iberia and Europe was initiated in the Pyrenees and migrated diachronically westwards (Teixell et al. 2018). The kinematics of the Alpine convergence, dominated by an overall north-south shortening, is relevant to understand how strain was accommodated during orogenesis. Previous structures favourably oriented for this stress system are likely to have been reactivated. In fact, this has been the case for the inversion of the previous normal faults oriented east-west, northwesterly directed normal faults and Variscan thrusts (e.g. Pulgar et al. 1999; Alonso et al. 2009; Llana-Fúnez \& López-Fernández 2015). The crust has a constant thickness of $30-35 \mathrm{~km}$ in the west and increases to 45-55 under the Central part of the Cantabrian Mountains (Fernández-Viejo et al. 2000; Díaz et al. 2016). The thickening occurs preferentially in the crust that had previously been extended during the two rifting episodes (Fernández-Lozano et al. 2012). In fact, there is a sharp gradient in thickness that coincides partly with the trace at the surface of the Ventaniella fault (Cadenas et al. 2018). 


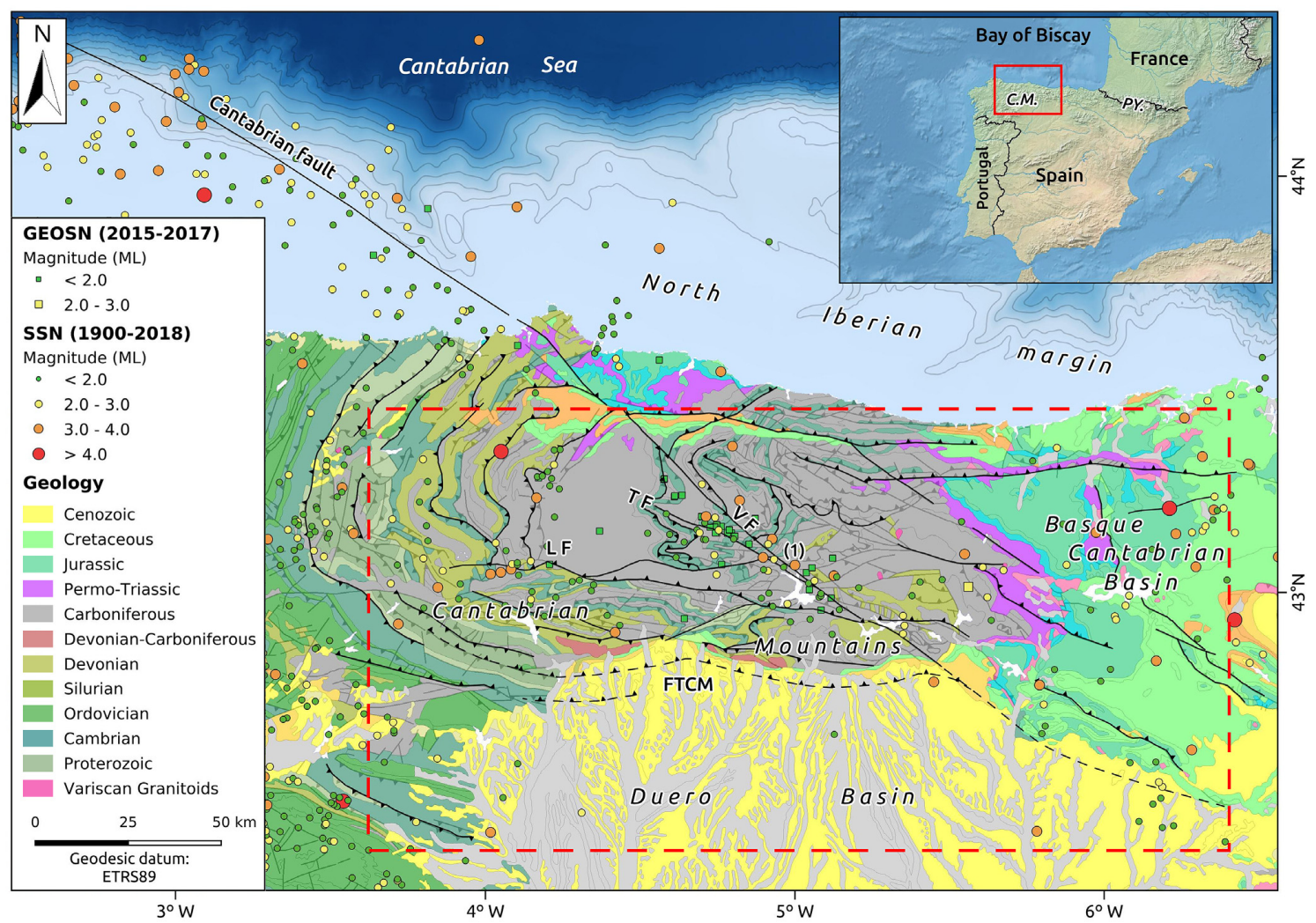

Figure 1. Geological setting of the study area (dashed red rectangle). Dots represent the seismic activity in the Cantabrian Mountains and surrounding areas in the 1900-2018 period. Seismicity data: Spanish Seismic Network (SSN) and Geocantábrica Seismic Network (GEOSN) (López-Fernández et al. 2018). C.M., Cantabrian Mountains; PY, Pyrenees; VF, Ventaniella fault, TF, Tarna fault; LF, León fault; FTCM, frontal thrust of the Cantabrian Mountains. (1) Epicentre location of the 1989 February 20 earthquake (3.7 mb $\mathrm{Lg})$. Geological background extracted from Geological Map of Spain 1/1 000000 (IGME 1994).

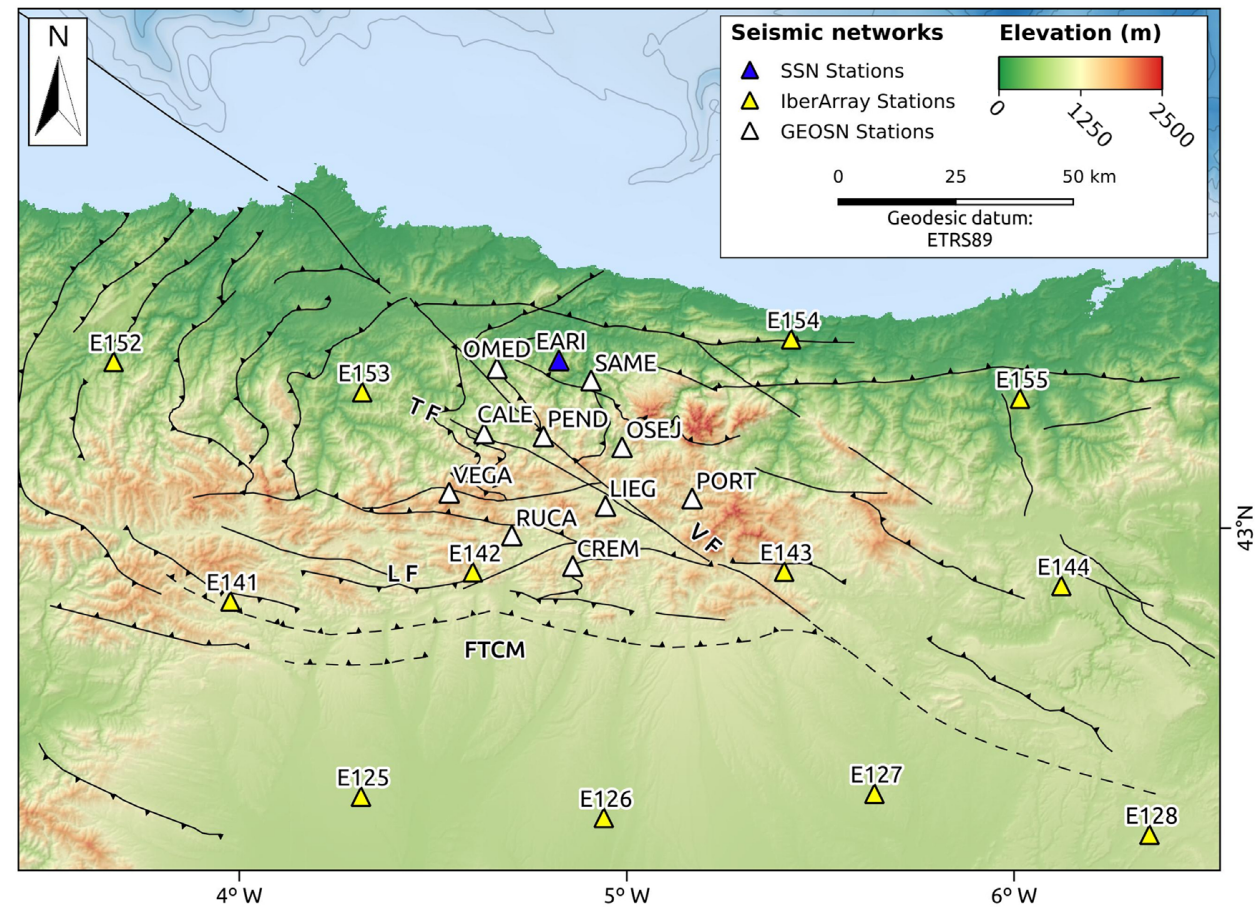

Figure 2. Topographic map of the study area. The yellow triangles are broad-band stations (plus the additional SSN broad-band station, the blue triangle). The white triangles represent short-period stations from the GEOSN experiment. 


\subsection{The Ventaniella fault and the frontal thrust of the Cantabrian Mountains}

The Ventaniella fault is a rectilinear crustal fault $320 \mathrm{~km}$ long on land and extending for more than another $150 \mathrm{~km}$ beneath the sea within the Bay of Biscay continental platform, where it is named as the Cantabrian fault (Fernández-Viejo et al. 2014; Fig. 1). A significant part of its current length offshore developed as a normal fault active during the Triassic extension. During this period, normal faults with similar orientation led to a thick Mesozoic sequence in the eastern block (Espina 1997). In the Cenozoic, the Alpine shortening reactivated it as a dextral strike slip fault (Julivert et al. 1971). It has an associated vertical component, elevating the northeastern block, which affects how the drainage network is organized. With the final docking of Iberia in Europe and the migration of the plate boundary to the south in the Azores-Gibraltar fracture, the area began its current passive stage of erosion.

The fault, however, shows evidence of recent tectonic activity, given its seismicity record and the presence of tectonic structures in Quaternary deposits in its southeastern end (Nozal \& Gracia 1990; López-Fernández et al. 2018). Although the fault is exposed at the surface, it is difficult to extract information at depth about its inclination and offset, given that the latter is difficult to resolve with current geophysics. Cadenas et al. (2018) have suggested the idea that the fault can be rooted in the lower crust. This is a working hypothesis for a number of recent studies focusing in the understanding of the structure of the fault throughout the crust.

The fault is favourably oriented for reactivation within the current stress state of NW Iberia (Andeweg et al. 1999; Herraiz et al. 2000; de Vicente et al. 2008; Olaiz et al. 2009), presenting lingering activity only at both ends, but with (historically) absent seismicity in its middle part (Fig. 1). In fact, onshore the fault constitutes a boundary between two domains, as to the east the crust in the vicinity of the fault shows sparse and low-magnitude seismicity (Fernández-Viejo et al. 2014; Lopez-Fernandez et al. 2018). The largest instrumental earthquake associated with this structure on land occurred in February 1989 with a $3.7 m_{\mathrm{b}} \mathrm{Lg}$ magnitude (Fig. 1).

In the most recent study, based in the observations by a detailed seismic network, a linear seismicity pattern was recorded plunging northwest, from a depth of $10 \mathrm{~km}$ in the south to almost $19 \mathrm{~km}$ depth to the northwest (cluster A in López-Fernández et al. 2018). The distribution of earthquakes coincides with the intersection of a secondary structure (Tarna fault), slightly oblique to the Ventaniella fault, with the frontal thrust of the Cantabrian Mountains, (LopezFernandez et al. 2018). This important inverse Alpine structure is a major north-dipping, low angle thrust that elevates the Cantabrian Mountains over the Duero basin in the south alongside other E$\mathrm{W}$ bearing inverse thrusts. It is responsible of the main shortening associated with the orogeny inland (Alonso et al. 1996; Fig. 1). Despite the fact that this structure is covered by modern Cenozoic sediments and it does not outcrop, it has been recognized in several seismic lines.

\subsection{Surface geology}

The northern half of the investigated area where stations were deployed can be divided in two parts attending to the surface geology. The northern sector is formed by a Cambro-Ordovician siliciclastic sequence at the base and Carboniferous limestones and shales at the top. The rock sequence is repeated numerous times by thrusting, everything folded by large subvertical structures, $10-20 \mathrm{~km}$ in wavelength with fold axis orientations varying from E-W at the south, progressively rotating to NW-SE to the north (Álvarez-Marrón et al. 1989; Alonso et al. 2009). The Ventaniella fault traverses this area from NW to SE.

On the other hand, the southern part is characterized by a strong structural imprint. Overall, it is characterized by east-west trending kilometric upright folding of smaller wavelength, $<5 \mathrm{~km}$, and the presence of several E-W subvertical faults, the main one being the León fault (Fig. 1). Some of the minor east-west faults have been reactivated during the Alpine orogeny and commonly present relatively wide damage zones associated with them.

This outcropping Palaeozoic basement has been uplifted during the Alpine cycle over two basins: the Basque-Cantabrian basin and the Duero basin. The Basque-Cantabrian basin is located in the easternmost part of the study area, and it is filled by a thick Mesozoic cover that was inverted during the convergence. Meanwhile, the Duero basin extends over the southern half of the area and it is formed by a mainly undeformed subhorizontal Cenozoic sequence.

\section{SEISMIC DATA}

This ambient noise study is based on data from 23 seismic stations, which are divided in two networks with different dimensions, technical characteristics and recording periods. The first seismic array is composed of 12 stations of the IberArray experiment (Díaz et al. 2009; Fig. 2), which covered completely the northern half of the Iberian Peninsula in its third stage (2011-2013). This network was augmented with a permanent broad-band station belonging to the Spanish Geographical Institute (IGN). All the stations were equipped with Nanometrics Taurus data loggers in combination with broad-band Nanometrics Trillium 120 s sensors. The spacing between stations was of approximately $60 \mathrm{~km}$, covering an area of $120 \times 250 \mathrm{~km}$. In total, we have processed 12 months (entire year 2012) of broad-band data from this experiment.

In September 2015, we deployed a temporary array of 10 shortperiod stations (Geocantábrica Seismic Network, GEOSN) in the southeastern sector of the Cantabrian Mountains (Fig. 2). Their distribution was designed with the main objective of improving earthquake location at depth (López-Fernández et al. 2018), but the recovered continuous seismic data has been used to analyse and process ambient noise, adding ray paths and enhancing resolution at short-periods in the area. The portable seismic network covers the $70-\mathrm{km}$ long active segment associated with the surface trend of the Ventaniella fault with a spacing between stations of approximately $15 \mathrm{~km}$, covering an area of roughly $60 \times 50 \mathrm{~km}$. By the end of the deployment, we had collected 19 months of seismic data with 24-bit-Worldsensing-Spidernano data loggers equipped with threecomponent, short-period Geospace MiniSeis-Monitor with $2 \mathrm{~Hz}$ natural frequency. These data loggers recorded at 100 samples s $^{-1}$ and were time-synchronized via GPS. The equipment was powered by solar panels and operated remotely through a Transmission Control Protocol/Internet Protocol.

\section{METHODOLOGY}

For the 123 station pairs, we have obtained a total of 34526 daily cross-correlations (21 011 from the IberArray network and 13515 from the GEOSN network) by using the PCC processing technique 
(Schimmel 1999). The cross-correlations of each station pair were stacked applying the tf-PWS methodology of Schimmel \& Gallart (2007). The EGFs obtained were calculated from the vertical components of the seismic noise recordings, assuring the emergence of Rayleigh waves. The following step was to measure the group velocities on the cross-correlated time-series. For this task, we used the multiple filtering analysis (MFA) of Dziewonski et al. (1969) for periods between 2 and $12 \mathrm{~s}$. Finally, tomographic maps of group velocities at different periods were computed with the Fast Marching Surface Tomography package (Rawlinson 2005) and inverted with the code surf96 (Herrmann \& Ammon 2002; Herrmann 2013) to obtain the $S$-wave velocity structure of the area.

\subsection{Data pre-processing}

The data pre-processing follows Bensen et al. (2007). For each station, the continuous data were cut into daily segments and decimated from 100 to 25 samples $\mathrm{s}^{-1}$ in order to optimize the running time of the correlation programs. The calculation of the classical cross-correlation (CCGN) began with the removal of the mean, the trend and the instrument response of the signal and the application of a band-pass filter between 0.01 and $2.0 \mathrm{~Hz}$ to the broad-band data and between 0.1 and $2.0 \mathrm{~Hz}$ to the short-period data. Then we applied a spectral whitening and a temporal normalization using the running-absolute-mean method (Bensen et al. 2007, 2008). With the objective of selecting the best technique to process our data, PCC was also calculated. The pre-processing of the PCC is similar to the one applied to the CCGN, except that no amplitude or frequency normalization is done. This is because PCC is amplitude unbiased, which means that the influence of high-amplitude energetic features is removed (Shimmel et al. 2011).

\subsection{Cross-correlation, stacking and signal emergence}

The daily cross-correlations were computed with the two abovementioned techniques, PCC and CCGN, for a positive and a negative time lag of $150 \mathrm{~s}$ for broad-band data and $60 \mathrm{~s}$ for short-period data. After removing incomplete or anomalous daily traces, all station pairs were computed with a mean record length of 270 daily timeseries of ambient noise recordings, ensuring the stability of the measurements. The majority of the cross-correlations show a visible asymmetry between their positive and negative components, which is generally higher in $\mathrm{E}-\mathrm{W}$ oriented paths than in the $\mathrm{N}-\mathrm{S}$ ones. Consistently with these observations, Chevrot et al. (2007) have identified the generation area of secondary microseismic noise in the north Galicia margin, in a relatively small region where waves reach the coast of Galicia at a nearly normal incidence. This zone is located to the west of our study area.

After that, the cross-correlations are stacked with the tf-PWS technique of Schimmel \& Gallart (2007), a nonlinear stacking method where each sample of a linear stack is weighted by an amplitude-unbiased coherence measure (Schimmel \& Paulssen 1997). Given the characteristics of the tf-PWS, the best phase coherence weight is obtained by stacking the entire positive and the time-reversed negative parts of the cross-correlograms, obtaining the so-called symmetrical Green's functions and enhancing the signal. As it can be seen in Fig. 3(a), using PCC instead of CCGN (Fig. 3b), together with tf-PWS, represents the best combination in terms of signal emergence for both broad-band and short-period data sets and, accordingly, it was the approach selected in this study.
A total of 123 EGFs are represented in Fig. 3(c) sorted by interstation distance. As far as we only worked with vertical component data, the surface waves that emerge from the background noise are mainly short-period Rayleigh waves.

\subsection{Measurement of dispersion curves}

The dispersive character of the Rayleigh waves allows us to construct dispersion curves that represent the group velocity of the traveling waves at different periods. From the stacked crosscorrelations, we have calculated their dispersion curves by applying the MFA method of Dziewonski et al. (1969), as implemented in the package Computer Programs in Seismology (Herrmann \& Ammon 2002; Herrmann 2013). Then, group velocities in their fundamental mode, the most easily identified mode in interferometrically constructed surface waves, were picked manually, extracting the group velocity measurements (Fig. 4a). As it is represented in Fig. 4(b), dispersion curves from the broad-band data have been calculated for period ranges between 3 and $12 \mathrm{~s}$ whereas dispersion curves from the short-period data have been obtained between 2 and $4 \mathrm{~s}$. Group velocities of the last group are coherent with the tendency of the broad-band data dispersion curves (Fig. 4b), and they provide valuable information at shorter periods.

\subsection{Quality control}

A strict quality control of the group velocity data was executed in three steps: (1) measurement of group velocities and data selection, (2) stability of dispersion curves and (3) setting of a minimum wavelength criterion.

Our group velocities were calculated only from well-defined and reliable MFA ridges (Fig. 4a). In addition, the analysis was limited to periods with a number of group velocity measurements higher than 29 and standard deviations below 0.2. In practice, this fact restricts the usable velocity data to periods ranging from 3 to $12 \mathrm{~s}$ (Fig. 4b).

The stability of the dispersion curves and the EGF waveforms were checked by progressively stacking sets of 7, 30, 90 and all the station-pair available daily cross-correlations (Figs 5a and b). For both broad-band and short-period data, waveforms and dispersion measurements tend to stabilize when more than 90 crosscorrelations are stacked (Figs 5a and b), a much lower number than the one used in this work. In order to estimate group velocity uncertainties, we applied a bootstrapping method used by Matos et al. (2015). For each interstation path, we have computed the dispersion curves of 10 stacks made with the 75 per cent of all available daily cross-correlations, which have been selected randomly. The results show, on average, group velocity uncertainties smaller than 1 per cent for broad-band signals and below 1.5 per cent for short-period data (Fig. 5c).

Finally, we have set a minimum wavelength criterion for the group velocity measurements. Given the dimensions and configuration of our networks, we have only maintained in the calculation the interstation paths whose distances are longer than two wavelengths. A stricter application of this rule (the more common three-wavelength criterion) will lead to a loss of potentially useful data at the longest periods. This two-wavelength criterion has been applied previously in ambient noise studies (e.g. Shapiro et al. 2005; Kang \& Shin 2006; Brandmayr et al. 2016). Nevertheless, Luo et al. (2015) proved that reliable and consistent measurements can be obtained with short interstation distances, up to one wavelength. 
(a)

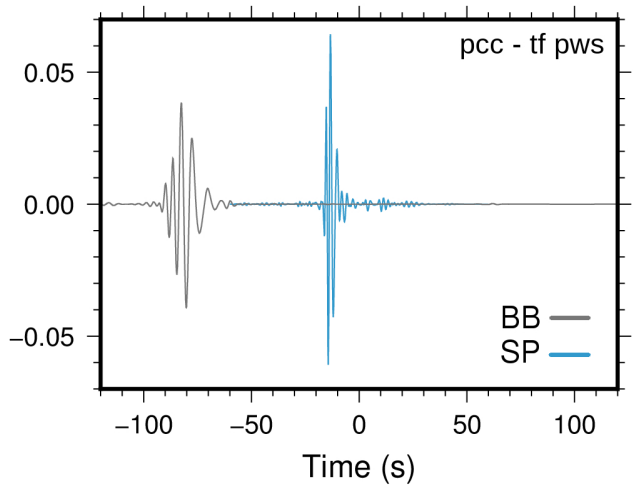

(b)

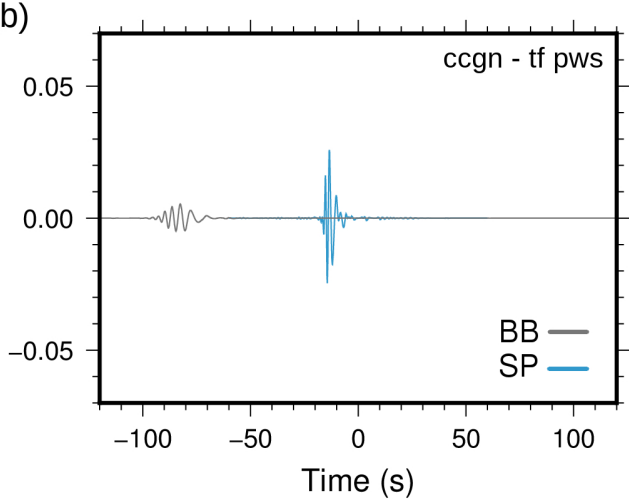

(c)

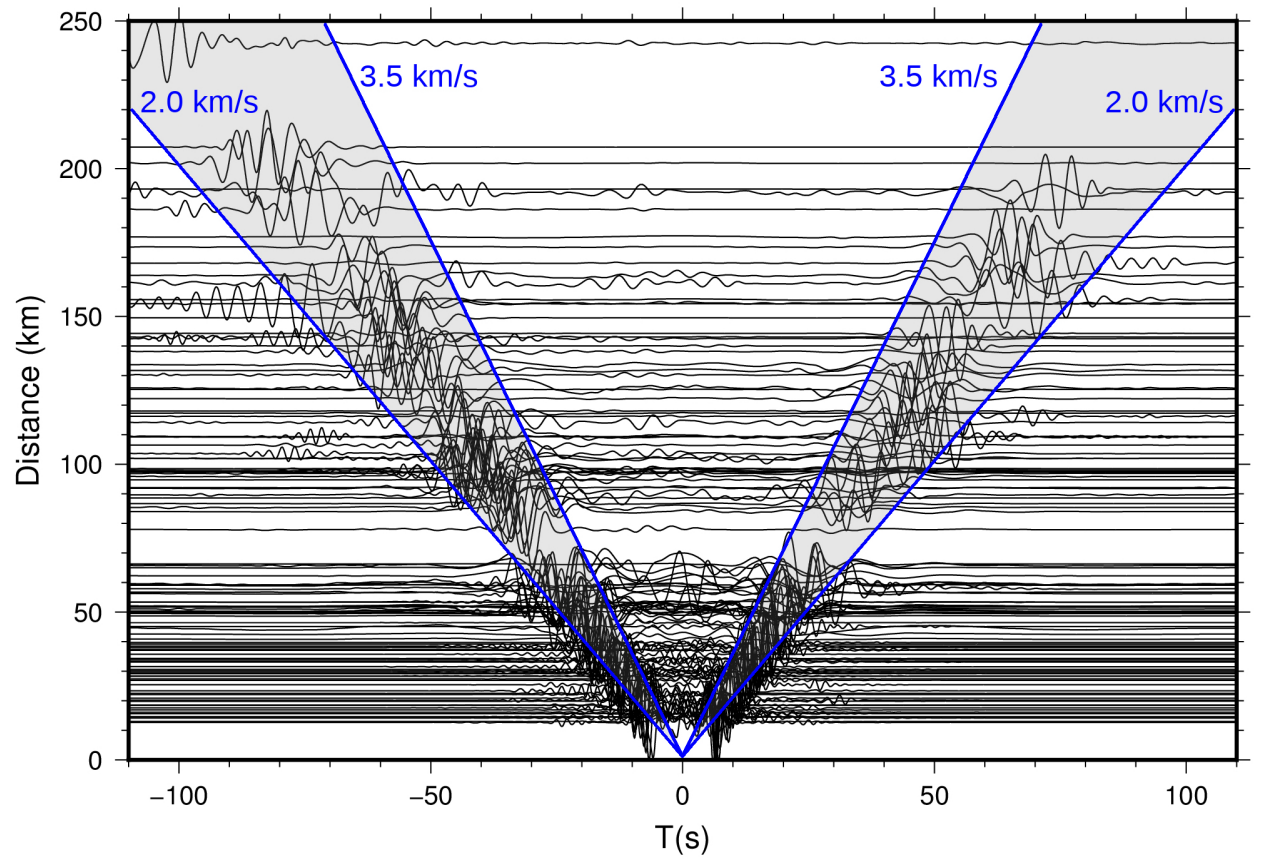

Figure 3. Examples of stacks of 260 daily ambient noise cross-correlations between two broad-band stations (BB, stations E144-E152) and two short-period stations (SP, stations LIEG-OMED) combining different techniques of cross-correlation with phase-weighted stacking. (a) PCC. (b) CCGN. Note how PCC enhances the signal amplitude in comparison with CCGN for both types of data sets. (c) Record section showing the EGFs of all station pairs plotted according to the interstation distances. Note the emergence of the Rayleigh wave in the shaded zone between propagation velocities of 2.0 and $3.5 \mathrm{~km} \mathrm{~s}^{-1}$.

\section{RAYLEIGH-WAVE TOMOGRAPHY AND DEPTH INVERSION}

\subsection{Tomographic maps and estimation of resolution: errors and limitations}

Before performing the inversion with real data, we investigated the capability of the array to solve the velocity structure at different periods through the chequerboard test (e.g. Humphreys \& Clayton 1988; Inoue et al. 1990; Zhao 2015). Fig. 6 shows three chequerboard models with cell sizes of $25 \times 25,45 \times 45$ and $80 \times 80 \mathrm{~km}$, with a $0.4 \mathrm{~km} \mathrm{~s}^{-1}$ velocity perturbation and the inverted solution for 4,8 and $12 \mathrm{~s}$ period. At periods up to $4 \mathrm{~s}$ (Fig. 6), the presence of the short-period interstation paths allows us to resolve the Ventaniella fault area with the sufficient resolution to draw features between 20 and $25 \mathrm{~km}$ in length scale. However, outside the dimensions of that network, the velocity structure is not well resolved for perturbations of that size. In the case of an initial model with a cell size of $45 \times 45 \mathrm{~km}$, the recovered models are quite accurate up to
$8 \mathrm{~s}$. At $12 \mathrm{~s}$, the period limit of this study, signs of smearing are observed in the inverted models of all cell sizes and anomalies tend to elongate in NE-SW direction. This decay of the resolution power is explained by the decrease in the number of paths at progressively longer periods.

In general, for all cell dimensions and periods investigated, anomalies are better resolved in the northern half of our study area. This is because a higher number of interstation paths cross this area. In conclusion, the resolution seems enough to draw features over $45 \mathrm{~km}$ in length scale, with an enhanced resolution at shorter periods in the northern central sector of the study area, where structures up to $25 \mathrm{~km}$ can be recognized. The RMS misfit between traveltime observations and traveltime predictions has been in all cases close to $1 \mathrm{~s}$ (e.g. $1.15,1.36$ and $0.86 \mathrm{~s}$ for periods of 4,8 and $12 \mathrm{~s}$ respectively), which ensures that the solution model fits the observed data and it is not affected by the choice of regularization parameters (Nicholson et al. 2012). 
(a)
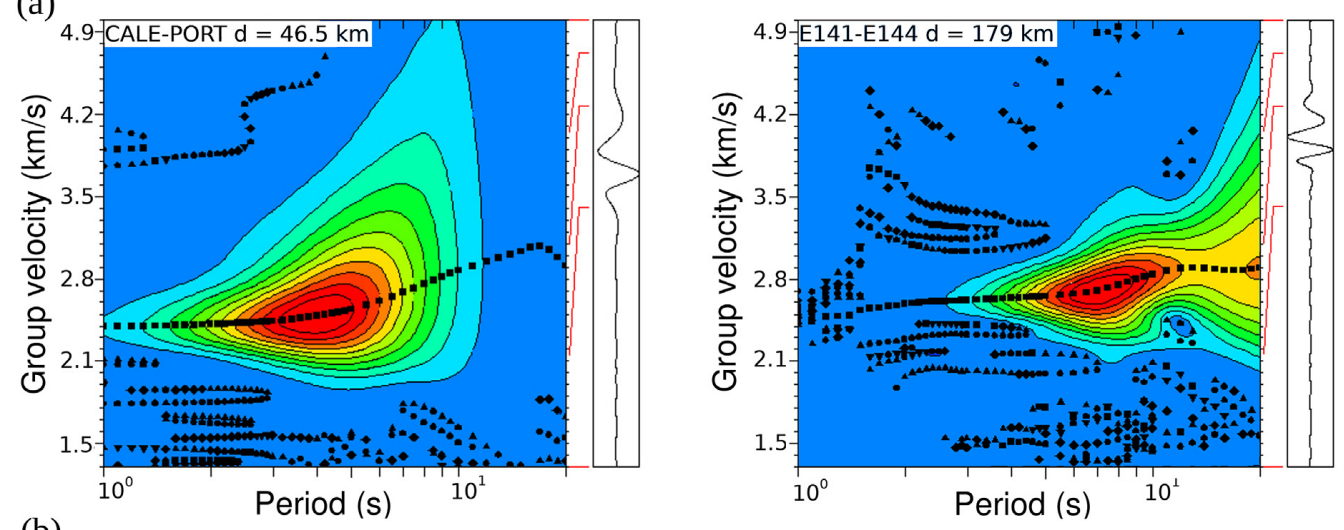

(b)

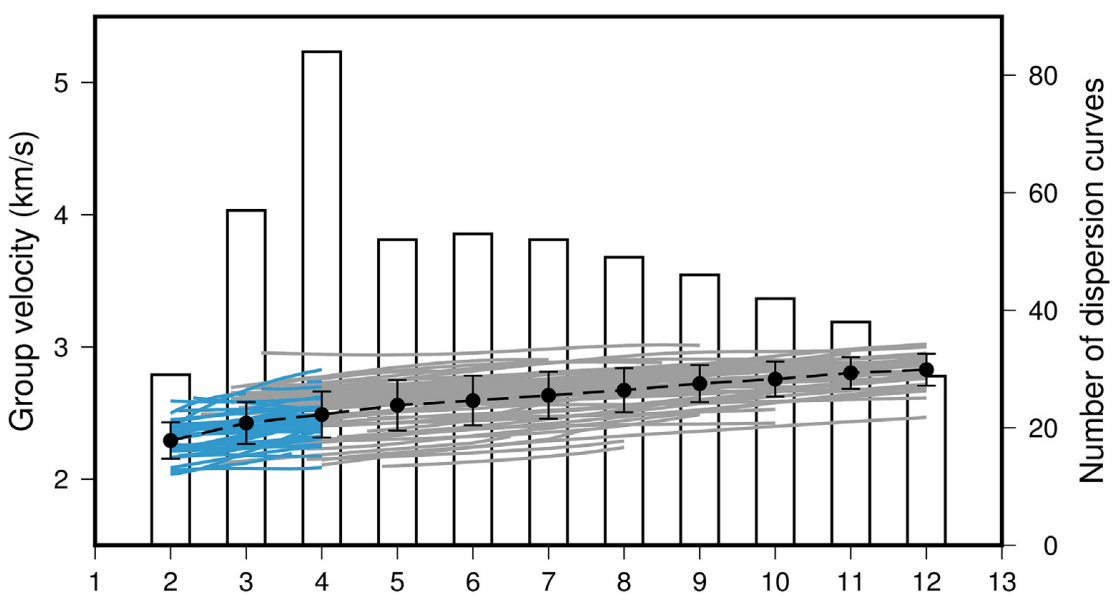

Figure 4. (a) Example of MFA surfaces for EGFs obtained between pairs of stations with different interstation distances $d$, showing the fundamental mode Rayleigh-wave group velocity dispersion curves. (b) Rayleigh-wave group velocity dispersion curves in the study area obtained from the GEOSN experiment (blue lines) and the IberArray experiment (grey lines). The black line shows the average velocity measurements for each period, with their respective standard deviations. Bars indicate the total number of dispersion curves as a function of signal period.

(a)
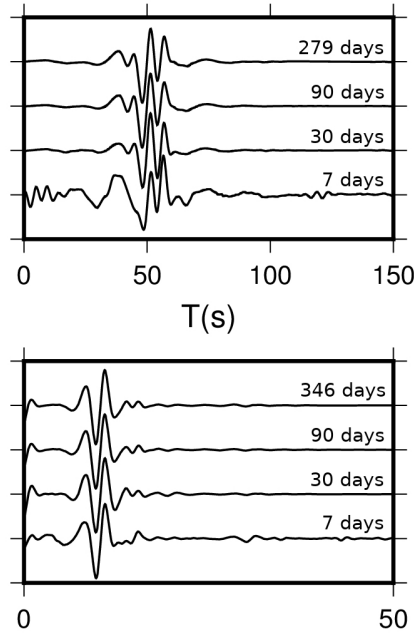

$\mathrm{T}(\mathrm{s})$

(b)
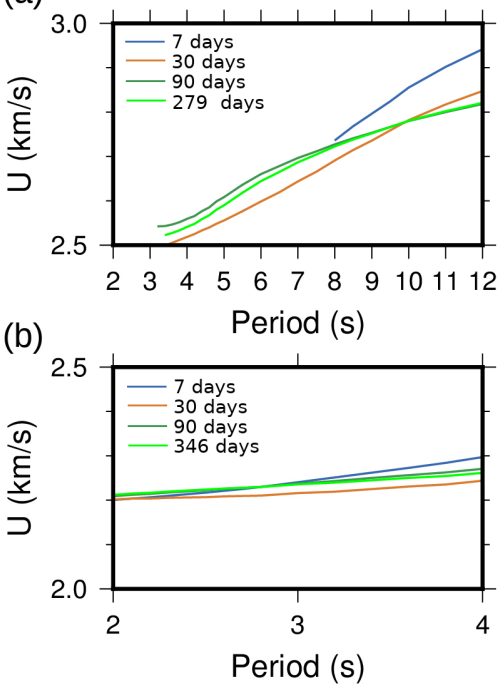

(c)

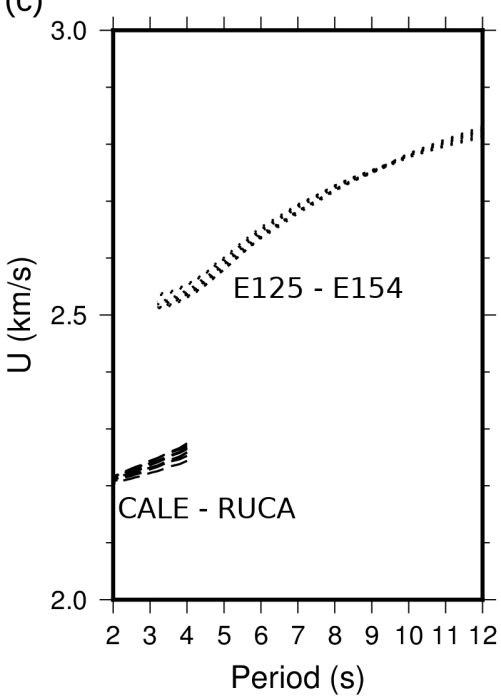

Figure 5. Example of sequential stacks of 7, 30, 90 and all-available daily cross-correlations (left) and corresponding dispersion curves obtained through MFA (centre) for the station pairs E125-E154 (a) and CALE-RUCA (b). Note the convergence of the cross-correlation stacks into the EGFs and the stability of the corresponding dispersion curves when $90 \mathrm{~d}$ are stacked. (c) Group velocity uncertainties for the interstation paths E125-E154 and CALE-RUCA. 

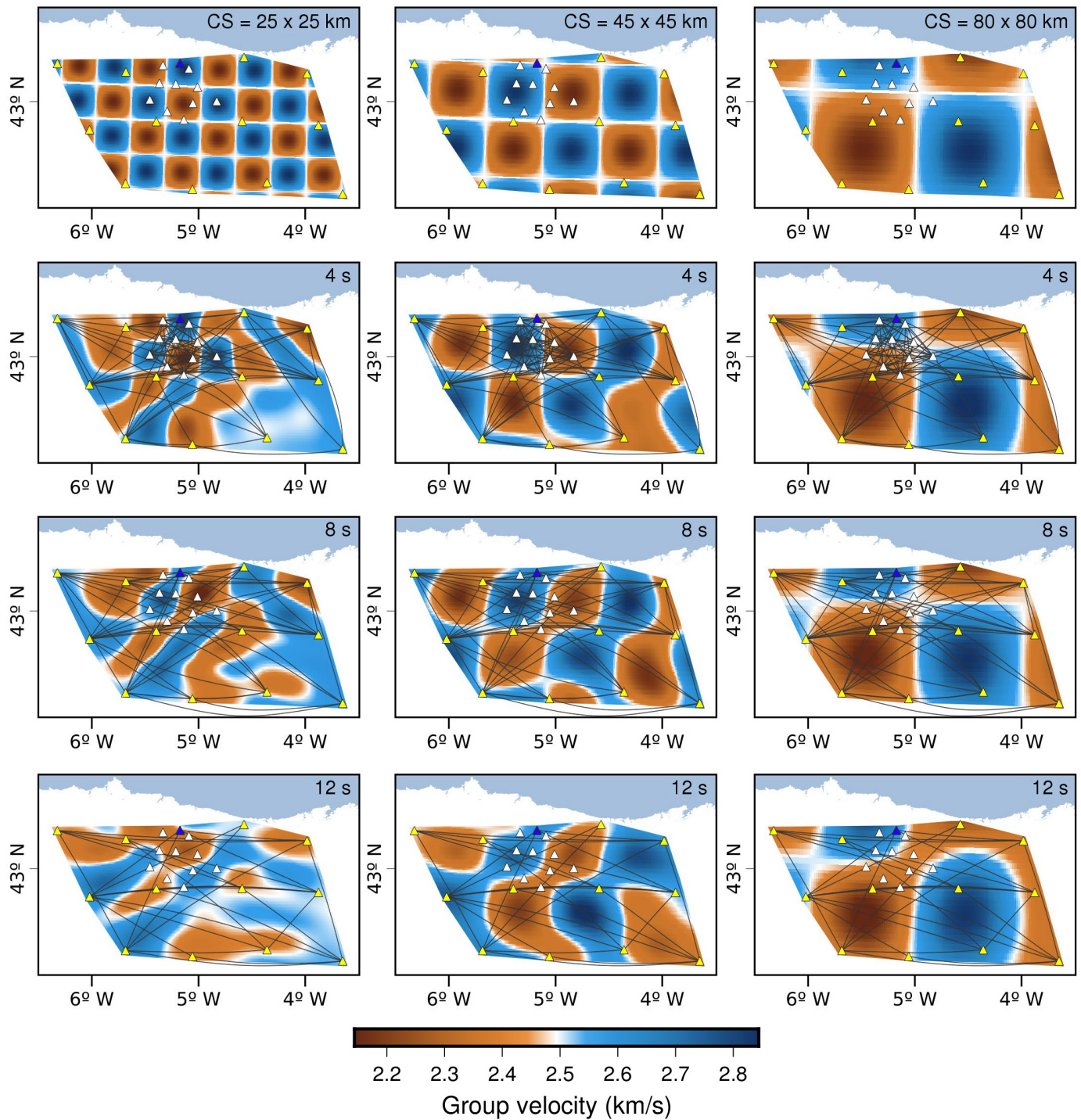

Figure 6. Synthetic chequerboard models with three different checker sizes $C S$ and inverted noise contaminated solutions for 4,8 and $12 \mathrm{~s} \mathrm{periods.} \mathrm{Triangles}$ represent seismic stations in Fig. 1.

\subsection{Rayleigh-wave group velocity tomography}

Dispersion curves of Rayleigh waves only represent the average velocity along the path between two receptors. In order to convert these data into a 2-D continuous space of velocities we employed the Fast Marching Surface Tomography Package (Rawlinson \& Sambridge 2005). We have inverted traveltime data sets from 3 to 12 s, following Rawlinson \& Sambridge (2005), Saygin (2007) and Nicholson et al. (2012). We chose a $11 \times 11 \mathrm{~km}$ grid for the inversions since it is smaller than the minimum length scale resolvable by the data, minimizing leakages of true Earth structures at length scales smaller than the resolvable feature size into our maps (Trampert \& Sneider 1996; Nicholson et al. 2012). The velocity of the homogeneous starting model was obtained from the average measured for a period (Nicholson et al. 2014). After numerous tests of these parameters, we set the damping and the smoothing factors to 0.001 and 0.1 respectively. However, their influence on the inversion results was rather low. Fig. 7 presents the resulting slices at selected periods of $4,6,8,10$ and $12 \mathrm{~s}$.

\subsection{Depth inversion}

From the set of group velocity maps obtained by tomography, we extracted the values of velocity for each point of our tomographic grid of $11 \times 11 \mathrm{~km}$. In practice, this represents a new local dispersion curve. The inversion of these local curves allowed us to derive 1 -D $S$-wave velocity depth functions in each node. For this task we used the code surf96 (Herrmann \& Ammon 2002; Herrmann 2013), which performs an iterative linearized least-squares inversion. Before running the inversion for each grid point, we calculated a regional velocity model to be used as the initial $S$-wave velocity structure. With the objective of addressing the non-uniqueness character of the depth inversion procedure, we have included published information from previous studies in the area. The starting model has a constant density value of $2670 \mathrm{~kg} \mathrm{~m}^{-3}$ and a fixed $S$-wave velocity of $3.35 \mathrm{~km} \mathrm{~s}^{-1}$. This velocity is based on body-wave velocities obtained in refraction profiles in the Cantabrian Mountains (Fernández-Viejo et al. 2000). The model was divided in 22 layers, the first four of them with a thickness of $0.5 \mathrm{~km}$ and the rest with a 

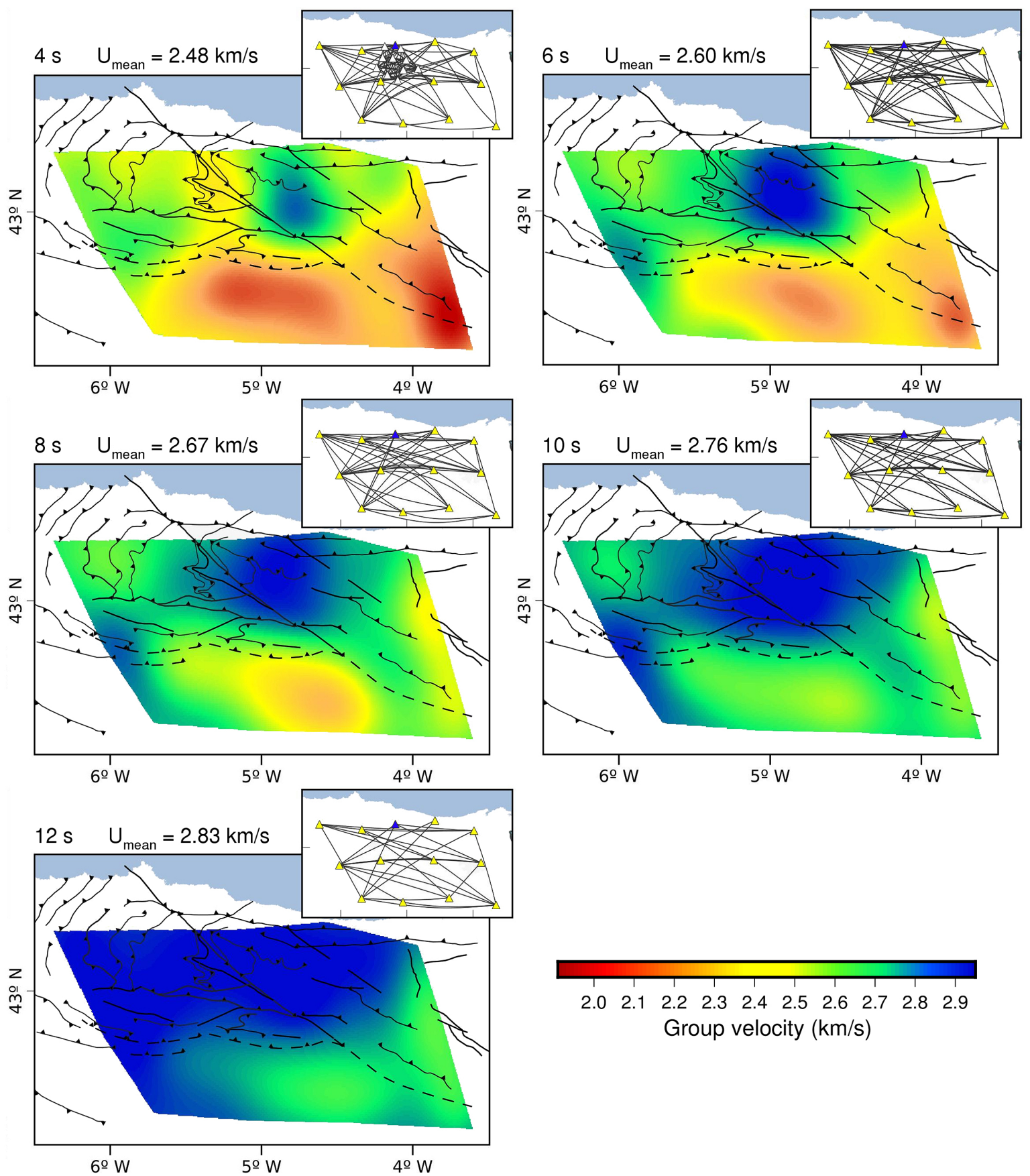

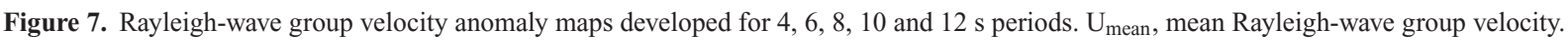

thickness of $1 \mathrm{~km}$. Next, we inverted the average dispersion curve of the study area (black line in Fig. 4b). The inversion resumed in 20 iterations. The damping factor was set to 10 in the first iterations to prevent from an excessive deviation from the initial model, using a value of 0.5 for the rest. These parameters were selected after extensive trial. Fig. 8(a) (black line) shows the regional model used as the initial reference to derive the 1-D depth functions.

The result, which includes 392 local Vs models, is shown in Fig. 8(a). The rugged topography of the study area, with elevation differences of up to $2000 \mathrm{~m}$, impeded the possibility of assuming a flat surface. Therefore, we applied a topographic correction by shifting each local 1-D model to the topographic elevation of the point of the grid, taking as reference the sea level (Benediktsdóttir et al. 2017). The effect of this correction is to make deeper structures shallower, and correspondingly changing the mean velocity value of the depth slices. However, this outcome is more notable at shallow depths, where layers are thinner.

\section{RESULTS}

\subsection{Rayleigh-wave group velocities}

The maps of Fig. 7 indicate that the absolute values of Rayleighwave group velocities in the Ventaniella area sampled by the seismic network range between 1.9 and $3.0 \mathrm{~km} \mathrm{~s}^{-1}$. For the shortest periods, up to $4 \mathrm{~s}$, two distinct blocks are observed in the north Ventaniella 
(a)

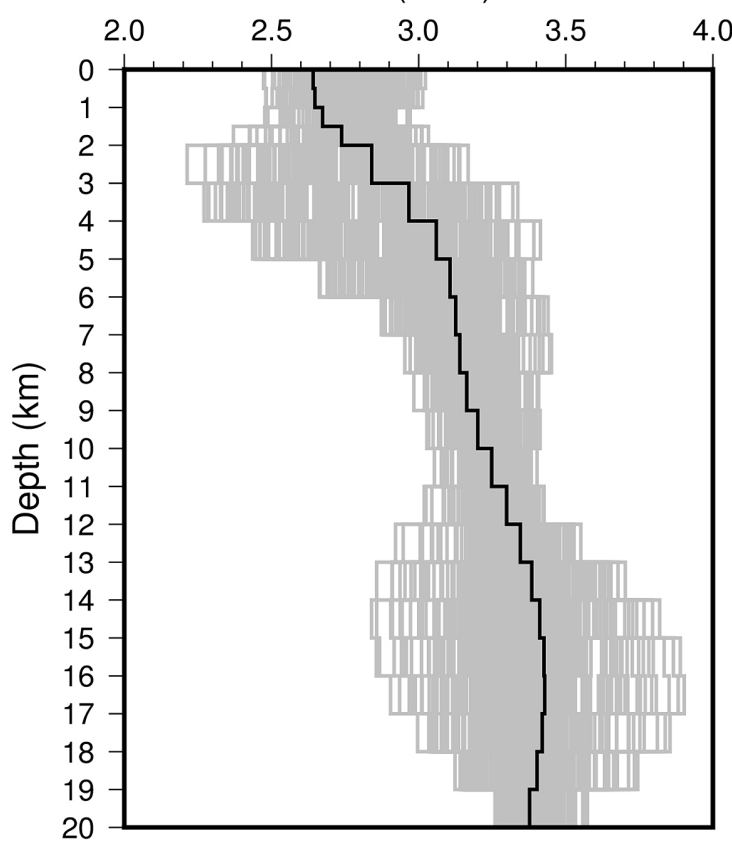

(b)

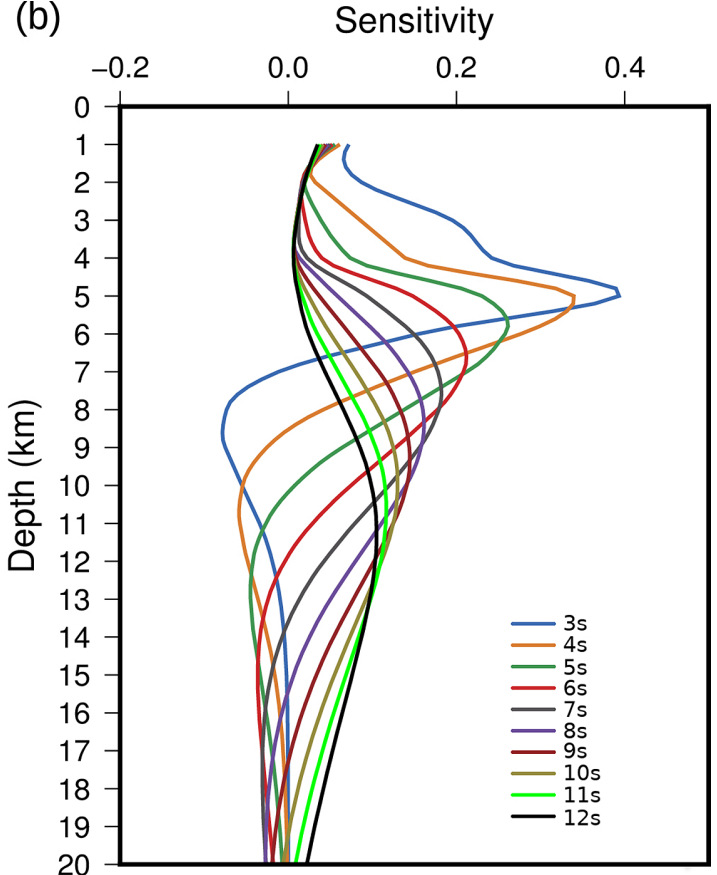

Figure 8. (a) $S$-wave velocity models derived for each grid node (grey lines) using as reference model the inverted regional model (black line). (b) Depth sensitivity kernels of the inversions.

fault area, a higher velocity block situated to the northeast in the hanging wall of the fault and a lower velocity area to the northwest of its trace. For periods over $6 \mathrm{~s}$, the faster anomaly in the east stands out turning into a progressively bigger rounded-shape body limited to the south by the trace of the León fault. This anomaly tends to expand at progressively higher depths towards the west, where it finally joins another fast velocity anomaly developed in the southwestern limit of the study area. In the southern half, two prominent low-velocity anomalies are observed at almost all periods. However, the apparent high-velocity corridor that separates them is likely to be an artefact caused by the lack of interstation paths in that area (Figs 6 and 7). It is worth noting that while absolute values of velocities increase steadily in the case of the low-velocity anomalies, they remain similar at all periods for the high velocities in the northern half of the area.

\section{$6.2 S$-wave velocities}

Fig. 9 shows the Vs models at 4, 6, 8, 10 and $12 \mathrm{~km}$ depth in terms of $S$-wave velocity perturbation (percentage of deviation from the mean Vs velocity at a certain depth). The mean $S$-wave velocities increase from $2.98 \mathrm{~km} \mathrm{~s}^{-1}$ at $4 \mathrm{~km}$ up to $3.32 \mathrm{~km} \mathrm{~s}^{-1}$ at $12 \mathrm{~km}$ depth. At the shallowest image displayed $(4 \mathrm{~km})$, a sector with lower velocities appears in the south and southeast, these anomalies delineate the Mesozoic and Cenozoic cover (Fig. 9) of the Duero and Basque-Cantabrian basins. The northern half of the area shows two relatively high anomalies, separated by a subtle NW-SE running corridor. For the slice at $6 \mathrm{~km}$ depth both high-velocity anomalies become less prominent, while the low-velocity corridor that separates them spreads. Down to $8 \mathrm{~km}$, these patterns continue and a new weak high-velocity anomaly appears, roughly separating the Duero basin and the Basque-Cantabrian basin. At $10 \mathrm{~km}$ depth, there is a perceivable change in the images due to the inversion of the northern high-velocity anomaly and the low-velocity corridor, which is also evident in the $12 \mathrm{~km}$ slice. At this range of depths, where the majority of the seismic activity has been located (López-Fernández et al. 2018) and important faults intersect, the reduction of the relative velocity reaches -5 per cent in the central Ventaniella fault area. The high-velocity lobe that separates the two basins disappears at $12 \mathrm{~km}$, and the high-velocity perturbation to the west stands out.

Shallower slices tend to depict the main geological units and structures of the Cantabrian Zone (Fig. 9). However, from $6 \mathrm{~km}$ downwards velocity perturbations become weaker and anomalies become harder to associate with geological features seen at the surface. Nonetheless, there is a general distinction between the northern sector of the study area, where high-velocity anomalies are more common, and the southern half, where low velocities are dominant. These two zones are roughly bounded by the frontal thrust of the Cantabrian Mountains and the León fault, both main E-W Alpine features of the Range.

In an attempt to visualize and illustrate the changes at depth in the area we have created two vertical cross-sections (Figs 10a and b) that intersect the main structures, extracted from the interpolation of slices of absolute $S$-wave velocity. Similar features can be observed in both cross-sections. The subvertical Ventaniella and León faults contrast with the dipping to the north frontal thrust of the Cantabrian Mountains, so at certain depth their interrelation is not as straightforward as the one shown at the surface. In the cross-section of Fig. 10(a), cutting perpendicularly the frontal thrust and the León fault, the lowest velocities are found in south. To the north, an elevated high-velocity block can be identified, limited by the frontal thrust. Under this block, as it was observed in the velocity perturbation maps, S-wave velocity decreases, coinciding with the area where the Ventaniella fault and the Tarna fault reach the frontal thrust of the Cantabrian Mountains.

On the other hand, the cross-section of Fig. 10(b) depicts a more elevated high-velocity block and a wider area of velocity reduction under it, where the frontal thrust of the Cantabrian Mountains and a blind thrust associated with this structure are expected to be located. 

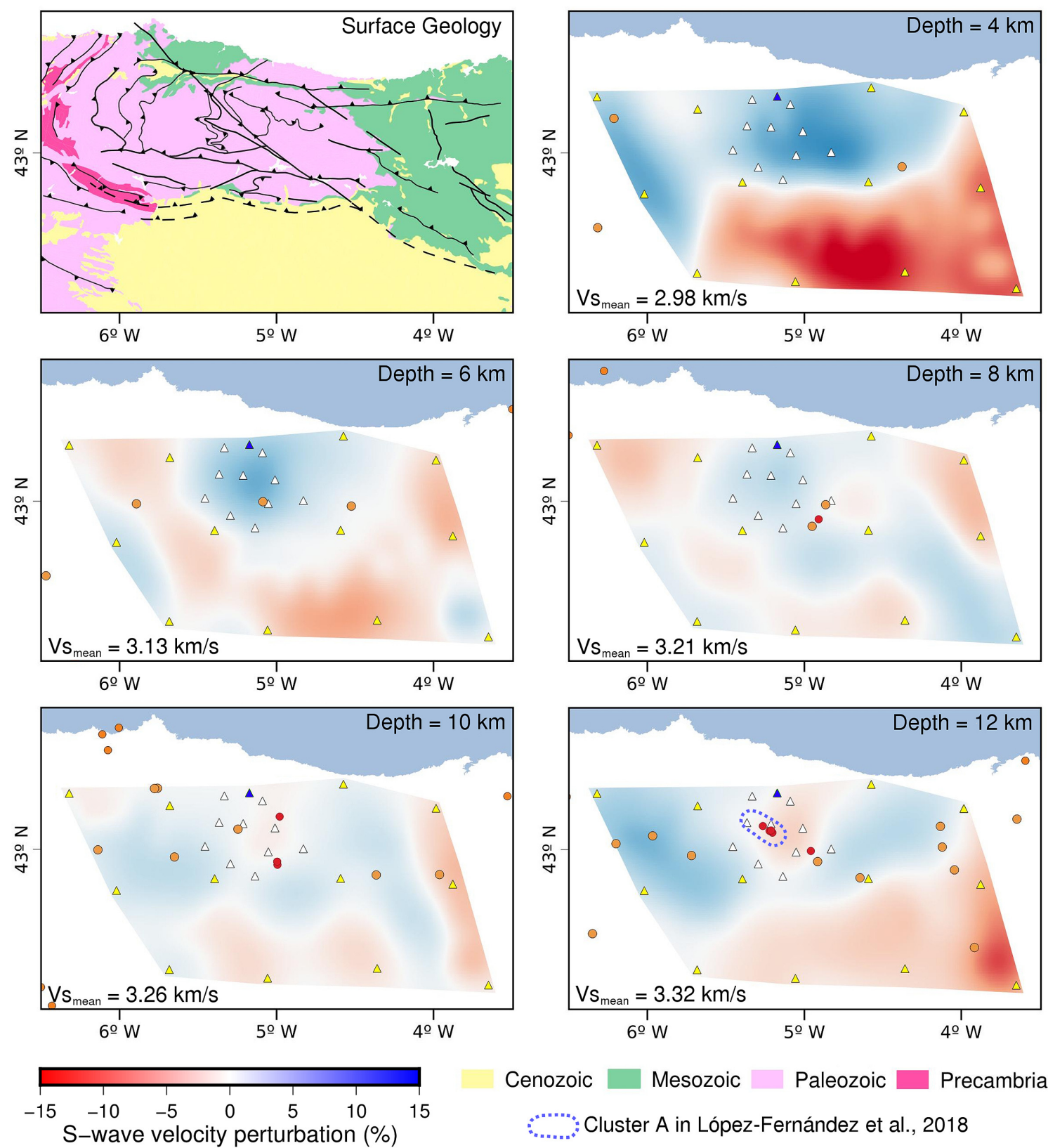

Cenozoic

Mesozoic

Paleozoic

Precambrian

: Cluster A in López-Fernández et al., 2018

Figure 9. $S$-wave velocity maps for 4, 6, 8, 10 and $12 \mathrm{~km}$ and simplified geological map of NW Spain. The orange dots represent the seismic activity in the area registered by the Spanish Seismic Network (1900-2018) and the red dots represent the seismic activity in the Ventaniella fault sector between September 2015 and March 2017 (López-Fernández et al. 2018) at the depth of each slice. Vs $s_{\text {mean }}$, mean $S$-wave velocity.

This cross-section is placed in the same location as the ESCIN-2 reflection profile (Fig. 10c) and close to the geological sketch of Fig. 10(d).

\section{DISCUSSION}

The results previously described in Figs 7 to 10 obtained with the analysis and study of the ambient seismic noise provide valuable insights to unravel the structure of the upper crust around seismicity clusters associated with the trace of the Ventaniella fault and its relationship with other large tectonic structures. Based on the sensitivity assessment performed (Fig. 8b) and the linear dependence of resolution with depth we must restrict the following discussion to the first $12 \mathrm{~km}$ of the crust, within a mechanically thick upper crust in current intraplate conditions, given that seismicity may be as deep as $19 \mathrm{~km}$ (Llana-Fúnez \& López-Fernández 2015).

For the shallowest slices and shorter periods obtained, a distinction is observed between the northwest (lower velocities) and northeast (higher velocities) of the study area, separated at the surface by the traces of the Ventaniella and León faults. The lowest velocities in these slices correspond to the materials of the Duero and Basque-Cantabrian basins, covering the southern and easternmost part of the investigated zone. The different velocity patterns can be related to differences in geological structure, orientation of bedding and tectonic structures and geological history. As it can be seen in the cross-sections of Figs 10(a) and (b), higher $S$-wave velocities are observed in the northern half of the study area at shallower depths than in the southern part. This high-velocity pattern 


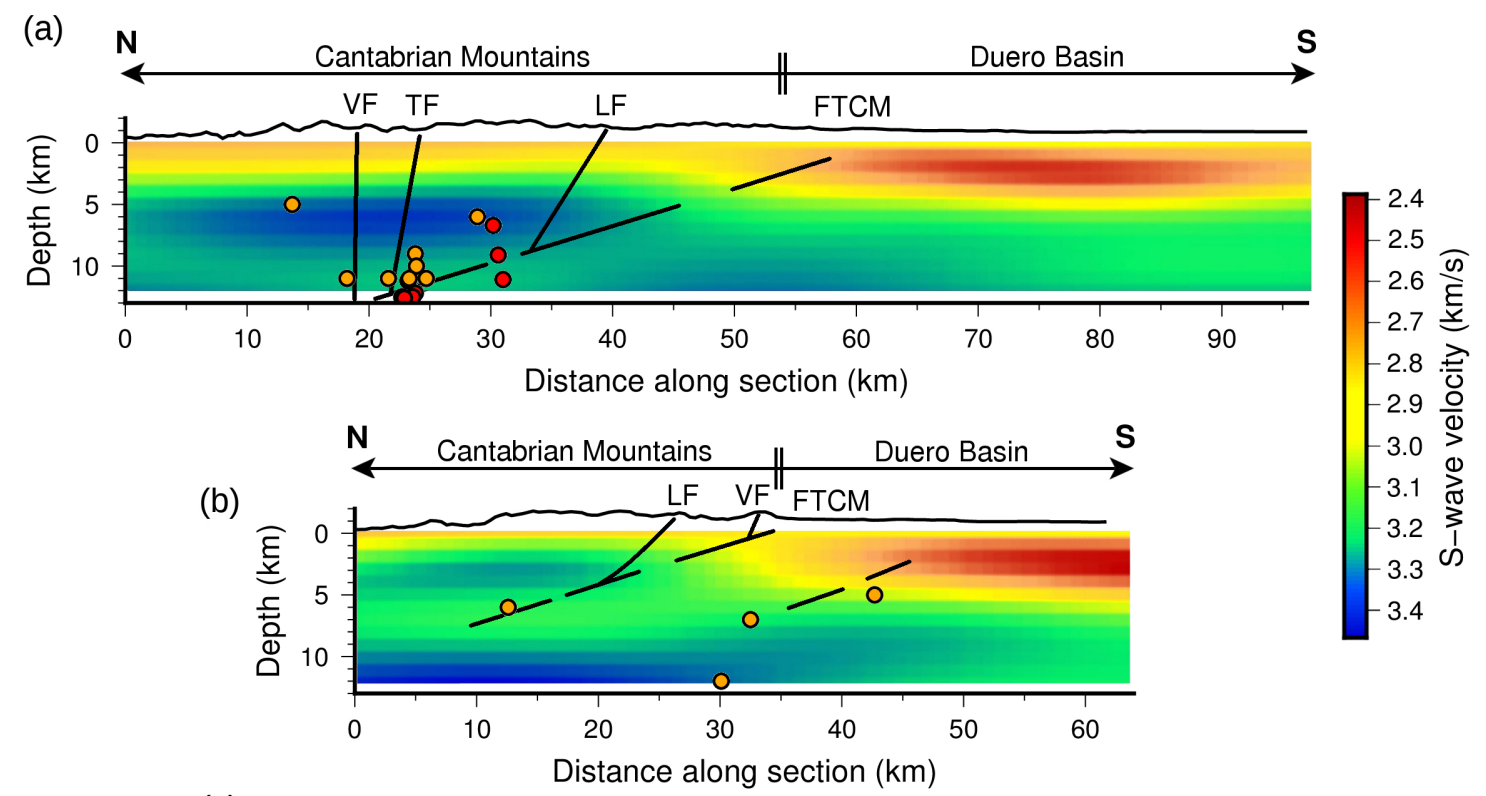

(c)

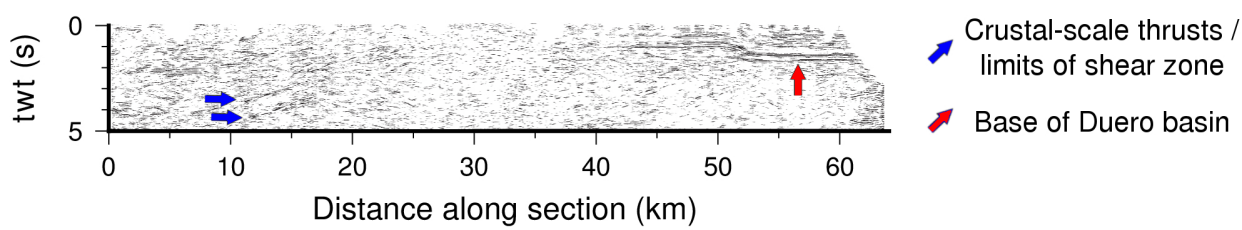

(d)
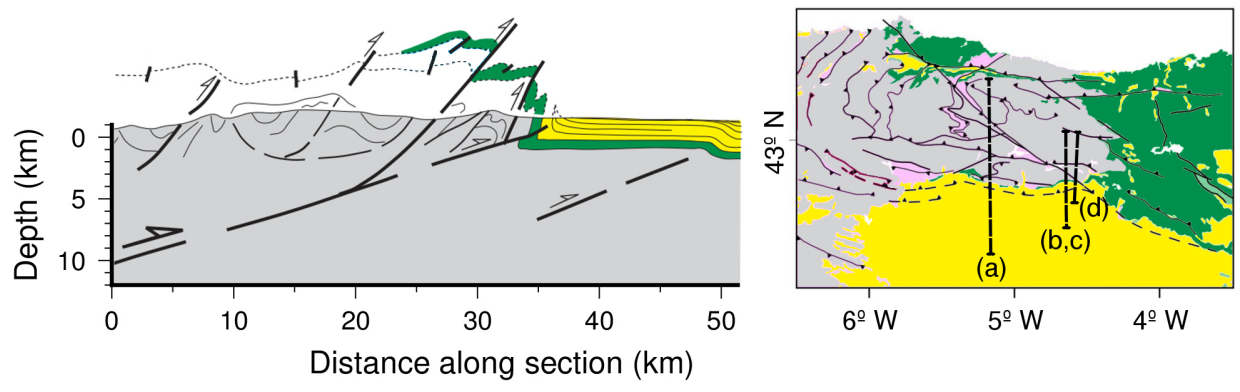

Cenozoic

Figure 10. (a) The north-south vertical profile across the study area, showing the absolute $S$-wave velocity structure at depth. The location of the cross-section is shown in Fig. 8. (b) The north-south vertical profile located in the same position as the ESCIN-2 profile. (c) Coherency filtered stack section of ESCIN-2 deep seismic reflection profile (adapted from Gallastegui et al. 2016). The arrows signal the reflectivity associated with the frontal thrust of the Cantabrian Mountains in the north and to the base of the Duero basin in the south. (d) The north-south cross-section showing the structure of the southern termination of the Cantabrian Mountains obtained from interpretation of geological data (adapted from Alonso et al. 1996) and geological sketch showing the position of the cross-section.

delineates an elevated block located under the Cantabrian Mountains, which supports the interpretation of the mountain range as a Palaeozoic basement block uplifted during the Alpine cycle. The deep seismic reflection profile ESCIN-2, Fig. 10(c) (Pérez-Estaún et al. 1994; Pulgar et al. 1995, 1996; Fernández-Viejo et al. 2000; Gallastegui 2000; Fernández-Viejo \& Gallastegui 2005; Gallastegui et al. 2016), located $50 \mathrm{~km}$ to the east from the position of the crosssection of Fig. 10(a) and in the same location as Fig. 10(b), depicts the duplication of the crust under the Cantabrian Mountains, the northern half of the study area. The elevated high-velocity block in both cross-sections can be associated with the uplifted Cantabrian margin middle crust, which is expected to be present at $4-5 \mathrm{~km}$ depth (Gallastegui et al. 2016). The limit between this block and the southern one is marked in the western cross-section (Fig. 10a) by a low-velocity corridor that dips around $20^{\circ} \mathrm{N}$. The position and dipping angle is in agreement with geological interpretations based on surface data in the area (Fig. $10 \mathrm{~d}, 16^{\circ}-18^{\circ}$ in Alonso et al. 1996) and suggests that this low-velocity zone may correspond to the fault zone in the hanging wall associated with the frontal thrust of the Cantabrian Mountains. In the eastern cross-section (Fig. 10b), crustal blocks are separated by a wide area of reduced velocities. In the ESCIN-2 profile, this fault zone is marked by the presence of two parallel north-dipping bands of reflectors (Fig. 10c) that have been interpreted as crustal scale thrusts (Gallastegui 2000; Gallastegui et al. 2016). From our results, it may be estimated that the reflectivity of both bands can be associated with the limits of the shear zone of the thrust, or alternatively correspond to two different structures. In the first case scenario, the thickness of the weakness zone associated with the thrust may be as much as 4-5 km. 
The east-west differentiation at shorter periods and shallow depths suggests the existence of a gradient in the elevation of the high-velocity block, sinking from east to west. This observation is coherent with the fact that the Alpine deformation migrated westwards in the study area, resulting in a higher dipping frontal thrust that accommodates more displacement in the eastern sector than in the western one (Alonso et al. 1996; Pulgar et al. 1999). The role of the León fault in the uplift of the high-velocity block (Alonso et al. 2007) is difficult to constrain with the current resolution, but it seems to border it at the shallowest depths (Fig. 10b). The Ventaniella and Tarna faults in turn, do not generate a perceptible vertical displacement in the high-velocity block, suggesting that both have accommodated strike-slip movements (Lopez-Fernandez et al. 2018). Nonetheless, the velocity patterns can also be affected by the fact that the Palaeozoic stratigraphic formations are vertically disposed in the eastern, hanging wall block, while they follow a sinuous pattern in the western block due to folding (Figs 1 and 9).

In terms of rock types, the area with the lower velocities, the Duero basin, is filled by Cenozoic sandstones and conglomerates while in the Basque-Cantabrian basin Mesozoic rocks outcrop. The northern half of the study area is dominated by much older Carboniferous shales and limestones, much more deformed and with different orientation of stratigraphic layering and structural fabric.

At intermediate periods, the group velocity pattern shows a highvelocity anomaly that expands towards the west. However, the positive velocity perturbation is more restricted to the central Ventaniella fault area and, at $10 \mathrm{~km}$ depth, this anomaly becomes negative. The differences between the models from group velocities and $S$-wave velocities illustrate the gradual variation of the features of the group velocity maps due to the overlap of the Rayleigh-wave depth sensitivity kernels (Yang et al. 2010) and highlight the convenience of performing the depth inversion step for a suitable geological interpretation.

Within the deeper slices resolved by our models, a low-velocity perturbation can be interpreted in the area of the fault intersections, where the shallowest seismicity attributed to the Ventaniella fault area arises (Fig. 9; cluster A in Lopez-Fernandez et al. 2018). This feature is not locally restricted to the fault trace but to a wider zone that expands from $9 \mathrm{~km}$ depth downwards and contains the intersection planes between the Ventaniella, Tarna and León faults with the frontal thrust of the Cantabrian Mountains (Fig. 10a). In the cross-section located to the east (Fig. 10b) the velocity reduction is more pronounced and it is observed in a wider area than in the west. In this zone the main structures are closer, increasing the fracture density, and they intersect at shallower depths $(2-10 \mathrm{~km})$ than in the west. This $S$-wave velocity reduction in complex fault zones has been observed in other studies (e.g. Thurber et al. 2003; Li et al. 2004; Zigone et al. 2015). Fracturing related to fault zones and their associated damage zones changes elastic properties of rocks and facilitates the presence of fluids (Faulkner et al. 2006), both phenomena consistent with the velocity reductions observed here.

Earthquake generation in intraplate settings has been described in relation to intersecting faults (e.g. Talwani 1999; Hildenbrand et al. 2001; Gangopadhyay \& Talwani 2005; Bonini et al. 2016), also in this area (Lopez-Fernandez et al. 2018) and further to the west in the Cantabrian Mountains in relation to conjugate strike-slip faults (Llana-Fúnez \& López-Fernández 2015). Intersecting faults can have strain rates 2 or 3 orders of magnitude higher than average continental crust (Talwani 1999). It is to be expected that an area where all these large structures interact will have at least a higher fracture density and therefore, prone to facilitate the presence of crustal fluids in comparison to the surrounding crust (e.g. Rice 1992;
Li et al. 2004). The results from the seismic noise tomography seem to corroborate this idea. Fig. 10(a) shows how most of the earthquakes located at the investigated depths were located within the low-velocity perturbation. The nucleation of earthquakes indicates that conditions for release of the stress are met. Lopez-Fernandez et al. (2018) already suggested that these conditions may occur at the depth where Ventaniella fault (almost vertical) or its secondary branch, the Tarna fault, intersect with the low angle north directed thrust that correspond to the front of the Cantabrian Mountains. However, the study was based on a fine relocation of seismicity and physical properties of the area were just suggested based on the seismicity clusters position. With the new models and results from the interferometric study, we can provide better constraints of the physical properties and structure of the crust above cluster A, part of the seismically active sector of Ventaniella fault. This includes the description of an uplifted crustal block in the north of the study area, the delineation through the tomographic images of the trace of the frontal thrust of the Cantabrian Mountains and other secondary faults similarly oriented and finally the identification of an $S$-wave relatively low-velocity zone in the area where the main faults intersect. Seismic swarms at the western end of the Cantabrian Mountains, in the neighbouring region of Galicia, also develop in areas of fault interaction, but in that case subvertical strike-slip faults. The intersections of such conjugate subvertical faults facilitate the ascent of crustal fluids and modify slightly crustal seismicity patterns (see Llana-Fúnez \& López-Fernández 2015).

Comparing our local results with regional studies, the presence of a change of velocity contrast approximately in the direction of the Ventaniella fault has been previously reported in larger scale studies of the Iberian Peninsula at all depths. For instance, Diaz et al. (2016) in a receiver function study illustrated a change with the same strike as the Ventaniella fault that they report as belonging to the transition between the crust affected by the Alpine orogeny and the crust with Variscan signature. Silveira et al. (2013) in a study of ambient noise tomography of the whole peninsula also present a slice at $8 \mathrm{~s}$ period, where similar features and velocity ranges are seen. The velocity patterns around the Ventaniella fault are interpreted as the large-scale transition between the Variscan massif of the peninsula and the more recent Alpine crust to the east. In terms of $S$-wave velocities, our results are consistent with those found by Macquet et al. (2014) and Palomeras et al. (2017). At $5 \mathrm{~km}$ depth, they have obtained velocities in our study area that range between 2.5 and $3.5 \mathrm{~km} \mathrm{~s}^{-1}$.

In this contribution, besides confirming this first order change corresponding to the age of crustal blocks of the northwestern Iberian, the resolution and distinction between both upper crustal blocks on either side of frontal thrust of the Cantabrian Mountains reveal the fault zone. The Ventaniella and Tarna faults, to the depths where earthquakes start to nucleate, show an slightly lower velocity than the surrounding crust. The presence of these subtle velocity variations between blocks separated by faults illustrate the ability of the ambient noise methodology in seismically quiet areas to characterize at depth the geological structures present at the surface.

\section{CONCLUSIONS}

An interferometry study within the southern area of the Cantabrian Mountains in the NW of Spain provides information about the main tectonic features of this range and its relationship with velocity variations and seismicity. The objective of the study was to discover why seismicity was restricted to the southern segment of the 
Ventaniella fault and if tomography could reveal different physical properties between the area where seismicity clusters and the surrounding aseismic crust.

Regional tomographic studies already had made clear that across the fault there was a distinct change in crustal physical properties, to the NE and to the SW, related to the different tectonic and thermal histories during the extensional post-Variscan episodes and the later opening of the Bay of Biscay. The crust reflects that differential thermal and strain history. However, the underlying reason for the current seismicity pattern being only restricted to part of the fault awaited a clear explanation. The results of this local study centred in that segment have provided sufficient and robust data and models to unravel the puzzling behaviour of the fault.

In summary, on the basis of the data extracted from noise analysis the main conclusions of the study are as follows:

(1) The resulting models from the ambient noise analysis indicate that the dominant factors for the velocity variations within $2-3 \mathrm{~km}$ (Vs) from the surface and for the shorter periods (Rayleigh-wave group velocity) are the orientation and spatial arrangement of stratigraphic rock formations at both sides of the fault, and particularly the presence and orientation of tectonic fabric (discontinuities) at the scale of the crust. Velocities in this range of depths can be directly linked to the type, geological history and bedding of the rock formation and/or their fracturing patterns. In this sense, although traditionally seismic tomography provides important differences in deep domains of the Earth, it also serves as a useful tool to infer the position of geological features from the uppermost parts of the crust.

(2) From 3 to $4 \mathrm{~km}$ downwards, a velocity anomaly starts to appear in the northeastern sector. At the maximum depths resolved by the models, $(12 \mathrm{~km})$, the anomaly concentrates above the area where a seismic cluster was previously described.

(3) This velocity anomaly encloses the area where the Ventaniella fault, the Cantabrian frontal thrust and the Leon fault are closer based on their projection at depth from their mapped trace at the surface. Therefore, seismic tomography of ambient noise is useful to detect shear zones or weakness areas associated with geological structures mapped at the surface and whose projection at depth may have high uncertainty.

(4) Current seismicity observed along the southern segment of the fault is directly related to the crust affected by the intersection of major recent faults, where Ventaniella cuts other faults active during the Alpine convergence. The fracturing associated with all faults involved facilitates the conditions for stresses to be released producing low to moderate earthquakes recorded historically at the surface.

(5) The N-S cross-sections depict a north-dipping low-velocity (Vs) corridor interpreted as the deformation zone caused by the Alpine frontal thrust of the Cantabrian Mountains or as two parallel crustal-scale thrusts, one of them corresponding to the Cantabrian frontal thrust.

This contribution illustrates how interferometry in lowmagnitude seismic areas can be very useful and complementary to other techniques to constrain structures and crustal changes at kilometric scales. An important application of these observations can be the improvement in assessing seismic hazard associated with structures whose depth prolongation is uncertain or poorly resolved.

\section{ACKNOWLEDGEMENTS}

\section{ACKNOWLEDGEMENTS}

The local data presented and used in this study were collected using a seismic network funded by projects MISTERIOSGEOCANTABRICA (https://doi.org/10.7914/SN/2M_2015) and can be released to the public on demand at GEOCANTABRICA@ftp.geol.uniovi.es. We would like to thank the ICTJA-CSIC Seismic Laboratory (http://labsis.ictja.csic.es) for sharing their seismic stations. The deployment of the IberArray broad-band seismic network (https://doi.org/10.7914/SN/IB) was part of the CONSOLIDER CSD2006-00041 (Geosciences in Iberia: Integrated studies on Topography and 4-D Evolution) grant from the Spanish Ministry of Science and Innovation. The Instituto Geográfico Nacional (IGN, Spain) is thanked for providing seismic data from the EARI permanent station. The regional seismicity data can be obtained from the Spanish Seismic Network at www.ign.es (last accessed March 2018). Data processing used Seismic Analysis Code v101.6a (Goldstein et al. 2003; Goldstein \& Snoke 2005) and Martin Schimmel's code Corr_stack_v04.1 (Schimmel et al. 2011). Tomography was performed with the Fast Marching Surface Tomography Package v1.1 (Rawlinson \& Sambridge 2005). Dispersion curves and $S$-wave velocity depth inversion were calculated with mft96 and surf96 codes, implemented in the Computer Programs in Seismology Package v3.30, January 2018 release (Herrmann 2013). Figures were drafted using the free software GIMP 2.8.20. Maps and cross-sections were constructed with Generic Mapping Tools 5.4.2 (Wessel \& Smith 1998) and QGIS 3.2. The study was funded by research grants GEOCANTABRICA (GRUPIN14-044) and MISTERIOS (MINECO-13-CGL2013-48601-C2-2-R). JA has a PhD grant 'Severo Ochoa' from the Asturias Government (PA-17PF-BP16139). Additional support from grant CGL2017-86487-P is acknowledged. Special thanks to Martin Schimmel for guidance and support on using his software package.

\section{REFERENCES}

Alonso, J.L., Pulgar, J.A., García-Ramos, J.C. \& Barba, P., 1996. Tertiary basins and Alpine tectonics in the Cantabrian Mountains, in Tertiary Basins of Spain, pp. 19-22, eds Friend, P.F. \& Dabrio, C.J., Cambridge Univ. Press.

Alonso, J.L., Marcos, A. \& Suárez, A., 2009. Paleogeographic inversion resulting from large out of sequence breaching thrusts: the León Fault (Cantabrian Zone, NW Iberia). A new picture of the external Variscan Thrust Belt in the Ibero-Armorican Arc, Geol. Acta, 7, 451-473.

Alonso, J.L., Martínez Abad, I. \& García-Ramos, J.C., 2007. Nota sobre la presencia de una sucesión cretácica en el Macizo de las Ubiñas (Cordillera Cantábrica). Implicaciones tectónicas y geomorfológicas, Geogaceta, 43, 47-50 (in Spanish).

Álvarez-Marrón, J., Heredia, N. \& Pérez-Estaún, A., 1989. Mapa geológico de la Región del Ponga, Trabajos Geol., 18, 127-135 (in Spanish).

Álvarez-Marrón, J., Rubio, E. \& Torne, M., 1997. Subduction-related structures in the north Iberian margin, J. geophys. Res., 102, 22 497-22 511.

Andeweg, B., De Vicente, G., Cloetingh, S., Giner, J. \& Muñoz Martín, A., 1999. Local stress fields and intraplate deformation in Iberia: variations in spatial and temporal interplay of regional stress sources, Tectonophysics, 305, 153-164.

Benediktsdóttir, A., Gudmundsson, O., Brandsdóttir, B. \& Tryggvason, A., 2017. Ambient noise tomography of Eyjafjallajökull volcano, Iceland, $J$. Volc. Geotherm. Res., 347, 250-263.

Bensen, G., Ritzwoller, M., Barmin, M., Levshin, A., Moschetti, M., Shapiro, N. \& Yang, Y., 2007. Processing seismic ambient noise data to obtain reliable broad-band surface wave dispersion measurements, Geophys. J. Int., 169, 1239-1260. 
Bensen, G., Ritzwoller, M. \& Shapiro, N., 2008. Broadband ambient noise surface wave tomography across the United States, J. geophys. Res., 113, $1-21$.

Berger, J., Davis, P. \& Ekström, G., 2004. Ambient Earth noise: a survey of the Global Seismographic Network, J. geophys. Res., 109, B11307, .

Boillot, G., Dupeuble, P.A. \& Malod, J., 1979. Subduction and tectonics on the continental margin of northern Spain, Mar. Geol., 32, 53-70.

Bonini, M. et al., 2016. Seismic sources and stress transfer interaction among axial normal faults and external thrust fronts in the northern Apennines (Italy): a working hypothesis based on the 1916-1920 time-space cluster of earthquakes, Tectonophysics, $\mathbf{6 8 0}, 67-89$.

Brandmayr, E., Kuponiyi, A.P., Arroucau, P. \& Vlahovic, G., 2016. Group velocity tomography of the upper crust in the eastern Tennessee seismic zone from ambient noise data, Tectonophysics, 688, 148-156.

Bussat, S. \& Kugler, S., 2009. Recording noise estimating shear wave velocities: feasibility of off-shore ambient-noise surface-wave tomography on a reservoir scale, in 79th Annual International Meeting, SEG, Expanded Abstracts, 1627-1631.

Cadenas, P., Fernández-Viejo, G., Pulgar, J.A., Tugend, J., Manatschal, G. \& Minshulll, T., 2018. Constraints imposed by rift inheritance on the compressional reactivation of a hyperextended margin: mapping rift domains in the north Iberian margin and in the Cantabrian Mountains, Tectonics, 37, 758-785.

Campillo, M. \& Paul, A., 2003. Long-range correlations in the diffuse seismic coda, Science, 299, 547-549.

Chevrot, S., Sylvander, M., Benahmed, S., Ponsolles, C., Lefevre, J.M. \& Paradis, D., 2007. Source locations of secondary microseisms in Western Europe: evidence for both coastal and pelagic sources, J. geophys. Res., 112, B11301,

Choukroune, R., ECORS Team, 1989. The ECORS-Pyrenean deep seismic profile reflection data and the overall structure of an orogenic belt, Tectonics, 8, 23-39.

Corela, C., Silveira, G., Matias, L., Schimmel, M. \& Geissler, W.H., 2017. Ambient seismic noise tomography of SW Iberia integrating seafloor- and land-based data, Tectonophysics, 700-701, 131-149.

De Vicente, G., Cloetingh, S., Muñoz-Martín, A., Olaiz, A., Stich, D., Vegas, R., Galindo-Zaldívar, J. \& Fernández-Lozano, J., 2008. Inversion of moment tensor focal mechanisms for active stresses around the microcontinent Iberia: tectonic implications, Tectonics, 27, TC1009,

Dias, R.C., Julià, J. \& Schimmel, M., 2015. Rayleigh-wave, group velocity tomography of the Borborema Province, NE Brazil, from ambient seismic noise, Pure appl. Geophys., 172, 1429-1449.

Díaz, J., Gallart, J. \& Carbonell, R., 2016. Moho topography beneath the Iberian-Western Mediterranean region mapped from controlled-source and natural seismicity surveys, Tectonophysics, 692, 74-95.

Díaz, J., Villaseñor, A., Gallart, J., Morales, J., Pazos, A., Cordoba, D., Pulgar, J. A., Garcia-Lobon, J. L., Harnafi, M. \& Topoiberia Seismic Working Grou, 2009. The IBERARRAY broadband seismic network: a new tool to investigate the deep structure beneath Iberia, ORFEUS Newslett., 8, 1-6.

Dziewonski, A., Bloch, S. \& Landisman, M., 1969. A technique for analysis of transient seismic signals, Bull. seism. Soc. Am., 59, 427-444.

Espina, R., 1997. La estructura y evolución tectonoestratigráfica del borde occidental de la Cuenca Vasco-Cantábrica (Cordillera Cantábrica, NO de España), $P h D$ thesis, University of Oviedo, Oviedo (in Spanish).

Faulkner, D.R., Mitchell, T.M., Healy, D. \& Heap, M.J., 2006. Slip on 'weak' faults by the rotation of regional stress in the fracture damage zone, Nature, 444, 922-925.

Fernández-Lozano, J., Sokoutis, D., Willingshofer, E., Dombrádi, E., Martín, A.M., De Vicente, G. \& Cloetingh, S., 2012. Integrated gravity and topography analysis in analog models: intraplate deformation in Iberia, Tectonics, 31, TC6005.

Fernández-Viejo, G. \& Gallastegui, J., 2005. The ESCI-N project after a decade: a synthesis of the results and open questions, Trabajos Geol., 25, 9-25.

Fernández-Viejo, G., Gallart, J., Pulgar, J.A., Gallastegui, J., Dañobeitia, J.J. \& Córdoba, D., 1998. Crustal transition between continental and oceanic domains along the north Iberian margin from wide angle seismic and gravity data, Geophys. Res. Lett., 25, 4249-4252.

Fernández-Viejo, G., Gallart, J., Pulgar, J.A., Córdoba, D. \& Dañobeitia, J.J., 2000. Seismic signature of Variscan and Alpine tectonics in NW Iberia: crustal structure of the Cantabrian Mountains and Duero basin, $J$. geophys. Res., 105, 3001-3018.

Fernández-Viejo, G., López Fernández, C., Domínguez-Cuesta, M.J. \& Cadenas, P., 2014. How much confidence can be conferred on tectonic maps of continental shelves? The Cantabrian-Fault case, Sci. Rep., 4, 3661.

Gallastegui, J., 2000. Estructura cortical de la cordillera y margen continental cantábricos: perfiles ESCI-N, PhD Thesis, Trabajos de Geología, 22, 1220 (in Spanish).

Gallastegui, J., Pulgar, J.A. \& Gallart, J., 2016. Alpine tectonic wedging and crustal delamination in the Cantabrian Mountains (NW Spain), Solid Earth, 7, 1043-1057.

Gangopadhyay, A. \& Talwani, P., 2005. Fault intersections and intraplate seismicity in Charleston, South Carolina: insights from a 2-D numerical model, Curr. Sci., 88, 1609-1616.

Goldstein, P. \& Snoke, A., 2005. SAC availability for the IRIS community, IRIS DMC Newslett., 7, 1-6.

Goldstein, P., Dodge, D., Firpo, M. \& Minner, L., 2003. SAC2000: signal processing and analysis tools for seismologists and engineers, in Invited Contribution to The IASPEI International Handbook of Earthquake and Engineering Seismology, eds Lee, W.H.K. et al., Academic Press.

Herraiz, M. et al., 2000. The recent (upper Miocene to Quaternary) and present tectonic stress distributions in the Iberian Peninsula, Tectonics, 19, 762-786.

Herrmann, R.B., 2013. Computer programs in seismology: an evolving tool for instruction and research, Seismol. Res. Lett., 84, 1081-1088.

Herrmann, R.B. \& Ammon, C.J., 2002. Computer Programs in Seismology Surface Waves, Receiver Functions and Crustal Structure, St. Louis University.

Hildenbrand, T.G., Stuart, W.D. \& Talwani, P., 2001. Geologic structures related to New Madrid earthquakes near Memphis, Tennessee, based on gravity and magnetic interpretations, Eng. Geol., 62, 105-121.

Hillers, G., Graham, N., Campillo, M., Kedar, S., Landès, M. \& Shapiro, N., 2012. Global and oceanic sources as seen by seismic arrays and predicted by wave action models, Geochem. Geophys. Geosyst., 13, Q011021.

Humphreys, E. \& Clayton, R.W., 1988. Adaptation of back projection tomography to seismic travel time problems, J. geophys. Res., 93, 1073-1085.

IGME, 1994. Mapa geológico de España a escala 1:1000000, Instituto Geológico y Minero de España.

Inoue, H., Fukao, Y., Tanabe, K. \& Ogata, Y., 1990. Whole mantle P wave travel time tomography, Phys. Earth planet. Inter., 59, 294-328.

Julivert, M., Ramírez del Pozo, J. \& Truyols, J., 1971. Histoire Structurale Du Golfe De Gascogne, Technip (in French).

Kang, T.S. \& Shin, J.S., 2006. Surface-wave tomography from ambient seismic noise of accelerograph networks in southern Korea, Geophys. Res. Lett., 33, L1.

Li, P. \& Lin, G., 2014. Adaptive ambient noise tomography and its application to the Garlock Fault, southern California, Geophys. J. Int., 197, 1236-1249.

Li, Y.G., Vidale, J.E. \& Cochran, E.S., 2004. Low-velocity damaged structures of the San Andreas Fault at Parkfield from fault zone trapped waves, Geophys. Res. Lett., 31, L12S06.

Lin, F., Moschetti, M. \& Ritzwoller, M., 2008. Surface wave tomography of the western United States from ambient seismic noise: Rayleigh and Love wave phase velocity maps, Geophys. J. Int., 173, 281-298.

Llana-Fúnez, S. \& López Fernández, C., 2015. The seismogenic zone of the continental crust in northwest Iberia and its relation to crustal structure, Tectonics, 34, 1751-1767.

López-Fernández, C., Fernández-Viejo, G., Olona, J. \& Llana-Fúnez, S., 2018. Intraplate seismicity in northwest Iberia along the trace of the Ventaniella fault: a case for fault intersection at depth, Bull. seism. Soc. Am., 108, 604-618.

Lopez-Gomez, J. et al., 2019. New lithostratigraphy for the Cantabrian Mountains: A common tectono-stratigraphic evolution for the onset of the 
Alpine cycle in the W Pyrenean realm, N Spain, Eart-Science Reviews, 188, 249-271.

Luo, Y., Yang, Y., Xu, Y., Xu, H., Zhao, K. \& Wang, K., 2015. On the limitations of interstation distances in ambient noise tomography, Geophys. J. Int., 201 652-661.

Macquet, M., Paul, A., Pedersen, H.A., Villaseñor, A., Chevrot, S., Sylvander, M. \& Wolyniec, D., PYROPE Working Group, 2014. Ambient noise tomography of the Pyrenees and the surrounding regions: inversion for a $3 \mathrm{D}$ Vs model in the presence of a very heterogeneous crust, Geophys. $J$. Int., 199, 402-415

Martín-González, F. \& Heredia, N., 2011. Complex tectonic and tectonostratigraphic evolution of an Alpine foreland basin: the western Duero Basin and the related Tertiary depressions of the NW Iberian Peninsula, Tectonophysics, 502, 75-89.

Matos, C., Silveira, G., Matias, L., Caldeira, R., Ribeiro, M.L., Dias, N.A., Krüger, F. \& Bento dos Santos, T., 2015. Upper crustal structure of Madeira Island revealed from ambient noise tomography, J. Volc. Geotherm. Res., 298, 136-145.

McNamara, D.E. \& Buland, R.P., 2004. Ambient noise levels In the Continental United States, Bull. seism. Soc. Am., 94, 1517-1527.

Mottaghi, A.A, Rezapour, M. \& Korn, M., 2013. Ambient noise surface wave tomography of the Iranian Plateau, Geophys. J. Int., 193, 452-462.

Mouthereau, F. et al., 2014. Placing limits to shortening evolution in the Pyrenees: role of margin architecture and implications for the Iberia/ Europe convergence, Tectonics, 33, 2283-2314.

Muñoz, J.A., 1992. Evolution of a continental collision belt: ECORSPyrenees crustal balanced cross-section, in Thrust Tectonics, 235-246, ed. McClay, K.R., Chapman and Hall.

Muñoz, J.A., 2002. Alpine tectonics I: the Alpine system north of the Betic Cordillera. Tectonic setting; the Pyrenees, in Geology of Spain, 370-385, eds Gibbons, W. \& Moreno, T., Geological Society.

Nicholson, H., Curtis, A. \& Baptie, B., 2014. Rayleigh wave tomography of the British Isles from ambient seismic noise, Geophys. J. Int., 198, 637-655.

Nicholson, H., Curtis, A., Baptie, B. \& Galetti, E., 2012. Seismic interferometry and ambient noise tomography in the British Isles, Proc. Geologists' Assoc., 123, 74-86.

Nozal, F. \& Gracia, F. J., 1990. El piedemonte de la Sierra del Brezo (Montes Palentinos), in Actas 1 Reunion Nacional de Geomorfología, 763-772, eds Gutiérrez-Elorza, M. \& Peña-Monné, J.L., Proc. I Reunion Nacional de Geomorfología (in Spanish).

Olaiz, A.J., Muñoz-Martín, A., De Vicente, G., Vegas, R. \& Cloetingh, S., 2009. European continuous active tectonic strain-stress map, Tectonophysics, 474, 33-40.

Palomeras, I., Villaseñor, A., Thurner, S., Levander, A., Gallart, J. \& Harnafi, M., 2017. Lithospheric structure of Iberia and Morocco using finitefrequency Rayleigh wave tomography from earthquakes and seismic ambient noise, Geochem. Geophys. Geosyst., 18, 1824-1840.

Pérez-Estaún, A., Pulgar, J.A., Banda, E. \& Álvarez-Marrón, J., ESCI-N Research Group, 1994. Crustal structure of the external Variscides in northwest Spain from deep seismic reflection profiling, Tectonophysics, 232, 91-118.

Picozzi, M., Parolai, S., Bindi, D. \& Strollo, A., 2009. Characterization of shallow geology by high-frequency seismic noise tomography, Geophys. J. Int., 176, 164-174.

Pulgar, J., Gallart, J., Fernández-Viejo, G., Pérez-Estaún, A. \& ÁlvarezMarrón, J., ESCIN Group, 1996. Seismic image of the Cantabrian Mountains in the western extension of the Pyrenees from integrated ESCIN reflection and refraction data, Tectonophysics, 264, 1-19.

Pulgar, J.A., Pérez-Estaún, A., Gallart, J., Álvarez-Marrón, J., Gallastegui, J. \& Alonso, J.L., Group ESCIN, 1995. The ESCIN-2 deep seismic reflection profile: a traverse across the Cantabrian Mountains and adjacent Duero basin, Rev. Soc. Geol. Esp., 8, 383-394 (in Spanish).

Pulgar, J.A., Alonso, J.L., Espina, R.G. \& Marín, J.A., 1999. La deformación alpina en el basamento varisco de la Zona Cantábrica, Trabajos Geol., 21, 283-294, (in Spanish).

Rawlinson, N., 2005. FMST: Fast Marching Surface Tomography Package, Research School of Earth Sciences, Australian National University.
Rawlinson, N. \& Sambridge, M., 2005. The fast marching method: an effective tool for tomographic imaging and tracking multiple phases in complex layered media, Explor. Geophys. 36, 341-350.

Rice, J.R., 1992. Fault stress states, pore pressure distributions, and the weakness of the San Andreas Fault, in Fault Mechanics and Transport Properties of Rocks, 475-503, eds Evans, B. \& Wong, T.F., Academic.

Roest, W.R. \& Srivastava, S.P., 1991. Kinematics of the plate boundaries between Eurasia, Iberia and Africa in the north-Atlantic from the Late Cretaceous to the present, Geology, 19, 613-616.

Ruiz, M., 2007. Caracterització structural i sismotectònica de la litosfera en el domini Pirenaico-Cantàbric a partir de mètodes de sísmica active $\mathrm{i}$ passive, PhD thesis, University of Barcelona, Barcelona (in Catalan).

Ryberg, T., Muksin, U. \& Bauer, K., 2016. Ambient seismic noise tomography reveals a hidden caldera and its relation to the Tarutung pull-apart basin at the Sumatra Fault Zone, Indonesia, J. Volc. Geotherm. Res., 321, $73-84$.

Sabra, K., Gerstoft, P., Roux, P., Kuperman, W. \& Fehler, M., 2005. Surface wave tomography from microseisms in Southern California, Geophys. Res. Lett., 32, L14311.

Saygin, E., 2007. Seismic receiver and noise correlation based studies in Australia, PhD thesis, The Australian National University, Canberra.

Schimmel, M., 1999. Phase cross-correlations: design, comparisons and applications, Bull. seism. Soc. Am., 89, 1366-1378.

Schimmel, M. \& Gallart, J., 2007. Frequency-dependent phase coherence for noise suppression in seismic array data, J. geophys. Res., 112, B04303.

Schimmel, M. \& Paulssen, H., 1997. Noise reduction and detection of weak, coherent signals through phase weighted stacks, Geophys. J. Int., 130, 497-505.

Schimmel, M., Stutzmann, E. \& Gallart, J., 2011. Using instantaneous phase coherence for signal extraction from ambient noise data at a local to a global scale, Geophys. J. Int., 184, 494-506.

Shapiro, N. \& Campillo, M., 2004. Emergence of broadband Rayleigh waves from correlations of the ambient seismic noise, Geophys. Res. Lett., 31, $1615-1619$.

Shapiro, N., Campillo, M., Stehly, L. \& Ritzwoller, M., 2005. High resolution surface-wave tomography from ambient seismic noise, Science, 307, $1615-1618$.

Silveira, G., Dias, N.A. \& Villaseñor, A., 2013. Seismic imaging of the Western Iberian crust using ambient noise: boundaries and internal structure of the Iberian Massif, Tectonophysics, 589, 186-194.

Slob, E., Draganov, D. \& Wapenaar, K., 2007. Interferometric electromagnetic Green's functions representations using propagation invariants, Geophys J. Int., 169, 60-80.

Snieder, R., 2004. Extracting the Green's function from the correlation of coda waves: a derivation based on stationary phase, Phys. Rev. E, 69, 046610.1.,

Stork, A.L., Allman, C., Curtis, A., Kendall, J.M. \& White, D.J., 2018. Assessing the potential to use repeated ambient noise seismic tomography to detect $\mathrm{CO} 2$ leaks: application to the Aquistore storage site, Int. $J$. Greenhouse Gas Control, 71, 20-35.

Talwani, P., 1999. Fault geometry and earthquakes in continental interiors, Tectonophysics, 305, 371-379.

Teixell, A., Labaume, P., Ayarza, P., de Saint Blanquat, M. \& Lagabrielle, Y., 2018. Crustal structure and evolution of the Pyrenean-Cantabrian belt: a review and new interpretations from recent concepts and data, Tectonophysics, 724-725, 146-170.

Thurber, C., Roecker, S., Roberts, K., Gold, M., Powell, L. \& Rittger, K., 2003. Earthquake locations and three-dimensional fault zone structure along the creeping section of the San Andreas Fault near Parkfield, CA: Preparing for SAFOD, Geophys. Res. Lett., 30, 1112.

Trampert, J. \& Sneider, R., 1996. Model estimations biased by truncated expansions: possible artifacts in seismic tomography, Science, 271, $1257-1260$.

Villaseñor, A., Yang, Y., Ritzwoller, M., Michael, H. \& Gallart, J., 2007. Ambient noise surface wave tomography of the Iberian Peninsula: implications for shallow seismic structure, Geophys. Res. Lett., 34, 1-5. 
Wang, Y., Lin, F.C., Schmandt, B. \& Farrell, J., 2017. Ambient noise tomography across Mount St. Helens using a dense seismic array, J. geophys. Res., 122, 4492-4508.

Wapenaar, K., 2003. Synthesis of an inhomogeneous medium from its acoustic transmission response, Geophysics, 68, 1756-1759.

Wapenaar, K., 2004. Retrieving the elastodynamic Green's function of an arbitrary homogeneous medium by cross correlation, Phys. Rev. E, 93, 254301.

Wapenaar, K., Ruigrok, E., van der Neut, J. \& Draganov, D., 2011. Improved surface-wave retrieval from ambient seismic noise by multi-dimensional deconvolution, Geophys. Res. Lett., 38, L01313.

Weaver, R.L. \& Lobkis, O.I., 2001. On the emergence of the Green's function in the correlations of a diffuse field, J. acoust. Soc. Am., 110, 3011-3017.
Wessel, P. \& Smith, W.H., 1998. New, improved version of generic mapping tools released, EOS, Trans. Am. geophys. Un., 79, 579-579.

Yang, Y., Ritzwoller, M., Levshin, A. \& Shapiro, N., 2007. Ambient noise Rayleigh wave tomography across Europe, Geophys. J. Int., 168, 259-274.

Yang, Y. et al., 2010. Rayleigh wave phase velocity maps of Tibet and the sorrounding regions from ambient seismic noise, Geochem. Geophys. Geosyst., 11, Q08010.

Zhao, D., 2015. Multiscale Seismic Tomography, pp. 21-54, Springer. Zigone, D., Ben-Zion, Y., Campillo, M. \& Roux, P., 2015. Seismic tomography of the Southern California Plate boundary region from noise-based Rayleigh and Love waves, Pure appl. Geophys., 172, 1007-1032. 